\title{
Spatio-temporal rainfall variability in the Amazon basin countries (Brazil, Peru, Bolivia, Colombia, and Ecuador)
}

\author{
Jhan Carlo Espinoza Villar,, a,b* Josyane Ronchail, ${ }^{\mathrm{b}}$ Jean Loup Guyot, ${ }^{\mathrm{c}}$ Gerard Cochonneau, ${ }^{\mathrm{c}}$ \\ Filizola Naziano, ${ }^{\mathrm{d}}$ Waldo Lavado, ${ }^{\mathrm{e}}$ Eurides De Oliveira, ${ }^{\mathrm{f}}$ Rodrigo Pombosa ${ }^{\mathrm{g}}$ \\ and Philippe Vauchel ${ }^{\mathrm{h}}$ \\ ${ }^{a}$ HydroGéodynamique du Bassin Amazonien (HYBAM)/IRD. UNALM - Lima, Peru, Université Paris 6 and LOCEAN (IRD, CNRS, MNHN, \\ UPMC) /IPSL, Boite 100, 4 Place Jussieu, 75252 Paris Cedex 05, France \\ ${ }^{\mathrm{b}}$ Université Paris 7 and LOCEAN \\ c LMTG (IRD-CNRS-UPS Toulouse), IRD CP 7091, Lago Sul, 71619-970 Brasilia (DF), Brazil \\ d UEA and I.PIATAM, Av. Ramos Ferreira, 199, 69010-120 Manaus-AM, Brazil \\ e SENAMHI/LMTG, Casilla 11 1308, Lima 11, Peru \\ ${ }^{\mathrm{f}}$ ANA, Setor Policia, CEP 70610-200, Brasilia, Brazil \\ g INAMHI, Quito, Ecuador, Iñaquito 700 y Correa, Quito, Ecuador \\ ${ }^{\text {h }}$ LMTG (IRD-CNRS-UPS Toulouse), IRD, Casilla 18-1209, Lima 18, Peru
}

\begin{abstract}
Rainfall variability in the Amazon basin (AB) is analysed for the 1964-2003 period. It is based on 756 pluviometric stations distributed throughout the $\mathrm{AB}$ countries. For the first time it includes data from Bolivia, Peru, Ecuador, and Colombia. In particular, the recent availability of rainfall data from the Andean countries makes it possible to complete previous studies. The impact of mountain ranges on rainfall is pointed out. The highest rainfall in the $\mathrm{AB}$ is observed in low windward regions, and low rainfall is measured in leeward and elevated stations. Additionally, rainfall regimes are more diversified in the Andean regions than in the lowlands. Rainfall spatio-temporal variability is studied based on a varimax-rotated principal component analysis (PCA). Long-term variability with a decreasing rainfall since the 1980s prevails in June-July-August (JJA) and September-October-November (SON). During the rainiest seasons, i.e. December-January-February (DJF) and March-April-May (MAM), the main variability is at decadal and interannual time scales. Interdecadal variability is related to long-term changes in the Pacific Ocean, whereas decadal variability, opposing the northwest and the south of the $\mathrm{AB}$, is associated with changes in the strength of the low-level jet (LLJ) along the Andes. Interannual variability characterizes more specifically the northeast of the basin and the southern tropical Andes. It is related to El Niño-Southern Oscillation (ENSO) and to the sea surface temperature (SST) gradient over the tropical Atlantic. Mean rainfall in the basin decreases during the 1975-2003 period at an annual rate estimated to be $-0.32 \%$. Break tests show that this decrease has been particularly important since 1982. Further insights into this phenomenon will permit to identify the impact of climate on the hydrology of the AB. Copyright (C) 2008 Royal Meteorological Society

KEY WORDS rainfall variability; rainfall regimes; Amazon basin; Andes; South American climate; Peru; Ecuador; Bolivia; Colombia; ENSO; PDO; LLJ
\end{abstract}

Received 24 July 2007; Revised 24 September 2008; Accepted 27 September 2008

\section{Introduction}

The Amazon basin $(\mathrm{AB})$ extends between $5^{\circ} \mathrm{N}$ and $20^{\circ} \mathrm{S}$ and from the Andes to the Atlantic Ocean, covering approximately $6000000 \mathrm{~km}^{2}$. Its fresh water contribution to the global ocean is $15 \%$ and its average discharge at the delta is $209000 \mathrm{~m}^{3} / \mathrm{s}$ (Molinier et al., 1996). The basin is divided into three great morphological units: $44 \%$ of its surface belongs to the Guyanese and Brazilian shields, $45 \%$ to the Amazon plain, and $11 \%$ to the Andes. This basin covers seven countries: Brazil (63\%), Peru

\footnotetext{
* Correspondence to: Jhan Carlo Espinoza Villar, LOCEAN (IRD, CNRS, MNHN, UPMC)/IPSL, Boite 100, 4 Place Jussieu, 75252, Paris Cedex 05, France. E-mail: jhan-carlo.espinoza@ locean-ipsl.upmc.fr
}

(16\%), Bolivia (12\%), Colombia (6\%), Ecuador (2\%), and Venezuela and Guyana (1\%).

$\mathrm{The} \mathrm{AB}$ is one of the regions with the highest rainfall in the world and a major water vapour source (Johnson, 1976; Ratisbona, 1976; Salati et al., 1978; Figueroa and Nobre, 1990). Also, it can undergo dramatic drought as observed in 2005 (Marengo et al., 2008; Zeng et al., 2008). Nonetheless, owing to a lack of information, few studies describe the spatio-temporal rainfall variability in the AB countries, except for Brazil. Cooperation programmes between Institut de Recherche pour le Développement/Institute for Research and Development (IRD) and local institutions have permitted, for the first time, the integration of data from the different Amazonian 
countries, highlighting a group of pluviometric stations unavailable so far, specially in the Amazon regions of the Andean countries (Bolivia, Peru, Ecuador, and Colombia). Nevertheless the need to consider comprehensive data set is important in the Andean regions. Rainfall tends to decrease with altitude, but the windward or leeward exposure of the stations to the dominant moist wind makes it difficult to find a simple relationship between rainfall and altitude (Johnson, 1976; Roche et al., 1990; Guyot, 1993; Pulwarty et al., 1998; Buytaert et al., 2006; Ronchail and Gallaire, 2006; Laraque et al., 2007). On the contrary, in Brazil, the spatiotemporal rainfall variability has been more widely studied and published than in the Andean countries. The highest values (3000-3500 mm/year) may be found in the northwest of the basin, on the border with Brazil, Colombia, and Venezuela, where the general large-scale relief shape, like the large concavities of the Andes eastern slope, creates favourable conditions for air convergence and large rainfall (Ratisbona, 1976; Salati et al., 1978; Nobre, 1983; Salati and Vose, 1984; Figueroa and Nobre, 1990). Abundant rainfall is also registered near the Amazon River delta where the sea-breeze effect is important (Salati et al., 1978). Salati et al. (1978) calculated a mean of $2400 \mathrm{~mm} / \mathrm{year}$ in the central region of the AB and Marquez et al. (1980) and Fisch et al. (1998) a mean $2300 \mathrm{~mm}$ rainfall for the Brazilian AB. Different studies, for the whole $\mathrm{AB}$, give values from 2000 to $3664 \mathrm{~mm}$, with the greater part between 2000 and $2200 \mathrm{~mm}$, as found by Marengo and Nobre (2001). Callède et al. (2008) report a 2230-mm mean annual rainfall for the $\mathrm{AB}$ down to Óbidos $\left(1.93^{\circ} \mathrm{S} 55.50^{\circ} \mathrm{W}\right.$, $800 \mathrm{~km}$ from the Amazon River delta), based on 163 rainfall gauges, including stations in the Andean countries, for the 1943-2003 period.

Rainfall regimes in the Brazilian Amazon show an opposition between the north and the south with rainy months in austral winter and summer, respectively (Ratisbona, 1976; Salati et al., 1978; Kousky et al., 1984; Horel et al., 1989; Figueroa and Nobre, 1990; Nobre et al., 1991, among others). A rainy period is observed in MAM in regions close to the Amazon River delta. A better distribution of rainfall over the year characterizes regions towards the border of Peru, Colombia, and Brazil. Among the limited number of studies devoted to the spatial variability of rainfall regimes in the Andean $A B$ that of Johnson (1976) is worth mentioning as this author analyses the seasonal regime of 107 rainfall gauges in Bolivia, Peru, and Ecuador. In Bolivia and southern Peru there exists a rainy period in austral summer and a dry period in winter, which is more intense in the west, inside the Andes (Johnson, 1976; Roche et al., 1990; Guyot, 1993; Aceituno, 1998). Laraque et al. (2007) complement the work by Johnson (1976) and detail the wide variability of regimes in the Ecuadorian $\mathrm{AB}$ based on 47 rainfall gauges, with opposite regimes in nearby zones. A better yearly rainfall distribution can be observed in the lowlands in the northeast of Peru (Weberbauer, 1945; Nicholson, 1948; Broggy, 1965).
Interannual rainfall variability in the $\mathrm{AB}$ partially depends on El Niño-Southern Oscillation (ENSO; Kousky et al., 1984; Aceituno, 1988; Marengo, 1992; Marengo and Hastenrath, 1993; Moron et al., 1995; Uvo et al., 1998; Liebmann and Marengo, 2001; Ronchail et al., 2002, among others). In particular, below normal rainfall is recorded in the north and northeast of the $\mathrm{AB}$ during El Niño events, whereas excess rainfall occurs during La Niña. This signal decreases towards the west and the south of the basin, and an inverse and weak signal can be observed in the Amazon plain of Bolivia (Ronchail, 1998; Ronchail et al., 2002, 2005; Ronchail and Gallaire, 2006), which may be related to the ENSO signal observed in the southeast of South America (the south of Brazil, Uruguay, and the northeast of Argentina). In the tropical Andes of Bolivia and the southern Andes of Peru, rainfall is below normal during El Niño event (Francou and Pizarro, 1985; Aceituno, 1988; Tapley and Waylen, 1990; Rome and Ronchail, 1998; Ronchail, 1998; Vuille et al., 2000; Garreaud and Aceituno, 2001; Ronchail and Gallaire, 2006), and the glacier meltdown accelerates during these years (Wagnon et al., 2001; Francou et al., 2003), while no clear signal can be found during La Niña events. In the north of the Peruvian Andes, no clear signal is found (Tapley and Waylen, 1990; Rome and Ronchail, 1998). The rainfall anomaly is not so pronounced in Ecuador (Rossel et al., 1999) with a slight rainfall increase during El Niño event for Ronchail et al. (2002) and Bendix et al. (2003) and a deficit for Vuille et al. (2000). The signal is also weak in the Colombian Amazon, where rainfall is abnormally abundant during La Niña events (Poveda and Mesa, 1993).

Long-term variability in the $\mathrm{AB}$ has been extensively reported in the literature. Chen et al. (2001) find a rainfall increase in the $\mathrm{AB}$ countries since the 1960s using data from Global Historical Climatology Network (GHCN). This is in line with the increase in humidity convergence, described by Chu et al. (1994) and Curtis and Hastenrath (1999). Nevertheless, this trend is not valid for Callède et al. (2004), who rebuilt a pluviometric series for the period 1945-1998 based on 43 pluviometric posts, and observe an slightly decreasing trend for the period, with the exception of high values recorded from 1965 to 1975. Marengo (2004) also finds this slight rainfall decrease in Brazil for the same period using data from Climate Research Unit (CRU), Climate Prediction Center Merged Analysis of Precipitation (CMAP), and 300 pluviometric stations from different local institutions. Also, Marengo and Nobre (2001) and Marengo (2004) show an opposition between the long-term rainfall evolution in northern and southern Amazon. In general, less rainfall has been recorded in the north since the late 1970s, whereas the opposite occurs in the south. These results are consistent with Ronchail (1996), with respect to rainfall in Bolivia and with Ronchail et al. (2005), who show an increase in the water level of the Madeira River during the 1970s. These findings may also be observed at the centre of Argentina (Agosta et al., 1999, among others), and in the discharge of the Paraná River in Paraguay 
(Genta et al., 1998; Robertson and Mechoso, 1998, etc.). Marengo (2004) attributes the rainfall increase in the southern Amazon to an intensification of the northeast trade winds and to the increase in water vapour transport from the tropical North Atlantic to the centre of the Amazon. For a shorter period (1978-1998) using CMAP data, Matsuyama et al. (2002) also present a decreasing rainfall trend in the north and an increasing trend in the south. Conversely, Zhou and Lau (2001) report a rainfall decrease as from 1986 to 1987 in the southwest of the basin, and an increase in the north. To account for this, the authors put forward the warming of the tropical South Atlantic and the shift of the intertropical convergence zone (ITCZ) to the south.

Rainfall variability is related to changes in the ocean and the atmosphere as mentioned before. However, it has also been linked to deforestation. In the $\mathrm{AB}$, deforestation has been considered as virtually non-existent till 1960 (Houghton et al., 2000), and the beginning of the $1970 \mathrm{~s}(0.34 \%$ of total land area being deforested in 1976, Callède et al., 2008). A compilation of the major works on the impact of deforestation on the $\mathrm{AB}$ rainfall has been presented by D'Almeida et al. (2007). It shows that the models developed at a macroscale $\left(>105 \mathrm{~km}^{2}\right)$ and simulating a general deforestation, evaluate a $0.40-1.70 \mathrm{~mm} /$ day rainfall decrease (Nobre et al., 1991; Henderson-Sellers et al., 1993; Dirmeyer and Shukla, 1994; Polcher and Laval, 1994; etc). Deforestation also causes the dry season to extend (Shukla et al., 1990; Nobre et al., 1991) and a strong rainfall decrease during the dry season (Silva Días et al., 2002). Nevertheless, the present human activity in the AB generates an intense deforestation in the southern and eastern basin principally and little deforestation in other regions, in particular, in the NW (Le Tourneau, 2004). That is why meso-scale deforestation models $\left(102-105 \mathrm{~km}^{2}\right)$ are relevant. On the one hand, they point out a rainfall decrease (Eltahir and Bras, 1994; etc), as well as a rainfall increase, as a result of increased albedo and causing convergence and convection in deforested zones (Chen and Avissar, 1994; Avissar and Liu, 1996; etc), particularly during the dry season (Wang et al., 2000; Durieux et al., 2003).

The aim of this paper is to provide a comprehensive study of spatio-temporal rainfall variability, using a new set of enriched data mainly originating from Peru, Bolivia, Ecuador, and Colombia. Likewise, it aims to identify the trend and evolution with time of the average annual rainfall in the basin countries. Within the framework of the Hydrology and Geodynamics of the Amazon Basin (HYBAM) programme, a rainfall variability analysis has been developed to assess the impact on discharge and sediment transport in the AB (Guyot, 1993; Gautier et al., 2006). This article first presents the data and the related spatial distribution, as well as an explanation of the different methods applied. The first part of the results focusses on spatial rainfall variability, then on regimes. In both cases the analysis is more detailed for Andean regions. Then, the space time interannual and pluriannual variability is analysed in relation to atmospheric circulation and to regional modes of ocean and atmosphere variability. Finally, the mean rainfall variability and trends are described for the whole $\mathrm{AB}$ during the 1975-2003 period. Discussions and conclusions are provided in the last section.

\section{Data and methods}

The HYBAM programme (http://www.mpl.ird.fr/hybam) has elaborated a monthly rainfall database, from in situ stations belonging to different institutions in charge of the meteorological and hydrological monitoring: Agência Nacional de Águas (Water National Office - ANA, Brazil), Servicio Nacional de Meteorología e Hidrología (National Meteorology and Hydrology Service SENAMHI, Peru and Bolivia), Instituto Nacional de Meteorología e Hidrología (National Meteorology and Hydrology Institute - INAMHI, Ecuador) and Instituto de Hidrología, Meteorología y Estudios Ambientales (Hydrology, Meteorology, and Environmental Studies Institute - IDEAM, Colombia). Brazilian data are freely available at http://www.ana.gov.br. Data from SENAMHI, IDEAM, and INAMHI are available on request. The database made up of a total of 1446 pluviometrical stations on a monthly basis has been submitted to the regional vector method (RVM) (Hiez, 1977 and Brunet-Moret, 1979) to assess its quality. Thus, for the same climatic zone experiencing the same rainfall regime, it is assumed that annual rainfall in the stations of the zone is proportional in-between stations, with little random annual variation as a result of rainfall distribution in the zone. The basic idea of the RVM is as follows: instead of comparing pairs of stations by correlation or double mass, a fictitious station is created as some 'sort of average or vector' of all stations in the zone, to be compared with every station (Hiez, 1977; Vauchel, 2005). To calculate this 'Vector' station, the RVM applies the concept of extended average rainfall to the work period, which is an estimation of the average possible value that would have been obtained through continuous observations during the study period. On the basis of the above, the least squares method is applied to find the regional annual pluviometric indexes $\boldsymbol{Z}_{i}$ and the extended average rainfall $\boldsymbol{P}_{j}$. This may be calculated by minimizing the sum of Equation (1), where $i$ is the year index, $j$ the station index, $\boldsymbol{N}$ the number of years, and $\boldsymbol{M}$ the number of stations. $\boldsymbol{P}_{i j}$ stands for the annual rainfall in the station $j$, year $i ; \boldsymbol{P}_{j}$ is the extended average rainfall period of $\boldsymbol{N}$ years; and finally, $\boldsymbol{Z}_{i}$ is the regional pluviometric index of year $i$. The series of chronological indexes $\boldsymbol{Z}_{i}$ is called 'regional annual pluviometric indexes vector'.

$$
\sum_{i=1}^{N} \sum_{j=1}^{M}\left(\frac{\boldsymbol{P}_{i j}}{\boldsymbol{P}_{j}}-\boldsymbol{Z}_{i}\right) .
$$

Two methods have been developed in parallel by Brunet-Moret (1979) and Hiez (1977), the main difference being the way in which the calculation of the 
extended average rainfall $\boldsymbol{P}_{j}$ is carried out. The first one considers that the extended average of a station is calculated using the mean observed values, after deleting outliers, i.e. data differing most from those of nearby stations for a particular year. The second one considers that the extended average of a station is calculated on the basis of the most frequent values (the mode) in accordance with the neighbouring stations. Therefore, there is no need to eliminate the data that differ considerably from the average, as it is carried out in the first method. In this study, Brunet-Moret's method has been applied, and the comparison with the other method has not yielded noticeable differences. On basis of these concepts, it is possible to analyse the data following an iterative process of station selection within a specific climatic region. The selection is supported by climatological maps and the description of rainfall regimes, as reported in previous studies. The iterative process calculates the vector, revises the results, separates inconsistent stations, calculates the vector once more, etc. Rejected stations close to the border of a region may present the behaviour of a neighbouring region. As a result, they are taken into account to calculate the vector of a new climatic region. Each resulting region is associated with a 'regional vector' that represents the interannual pluviometric variability in the region, and it is also similar to the behaviour of all the stations which are part of this region. Consequently, this vector is a good indicator of the climatic variability in the region. Thus for each year, this index requires data in at least five stations, to find the longest analysis periods per region. The application of the RVM in the $\mathrm{AB}$ led to 756 stations (52\% of the total) with data lasting more than 5 -year continuous periods, and less probabilities of errors in their series (Figure 1). On average, the data availability period is from 1975 to 2003, but, in the Andean countries, the series are generally longer and started in 1960 in Peru and in 1950 in Bolivia. In Colombia and Brazil, most records started between 1975 and 1980, with very few stations with data prior to 1965 .

The seasonal variability is analysed by means of percentage of rainfall on a quarterly basis from December-January-February (DJF) to September-OctoberNovember (SON). The seasonal variation coefficient (sVC) is calculated using the mean monthly rainfall. Likewise, the interannual variation coefficient (iVC) is computed using annual rainfall values.

The different seasonal regimes are analysed based on rainfall indexes that relate monthly rainfall to annual rainfall. Thus, stations can be classified according to their annual cycle and not on an amount of water. Equation (2) is used to calculate this index, where $\boldsymbol{I}_{i}$ is the monthly index for the month $i, \boldsymbol{P P}_{i}$ the monthly rainfall for month $i$, and $\boldsymbol{P P}_{\mathrm{A}}$ the total annual rainfall.

$$
\boldsymbol{I}_{i}=\frac{\boldsymbol{P P}_{i}}{\boldsymbol{P P}_{\mathrm{A}} / 12}
$$

An ascendant hierarchical classification (AHC) is applied to the monthly rainfall indexes to define the optimum number of clusters. The Ward method is applied to maximize inter-class variance. The $\mathrm{K}$-means method is then applied based on the number of groups found through AHC. This method relies on consecutive iterations permitting to decrease intra-group inertia and to increase inter-group inertia. The number of iterations was 10,15 , and 25 . Although groups can be created based on AHC, K-means permits to obtain several classifications and to identify stable and unstable stations (belonging to different clusters in different iterations). Only those stations belonging to the same cluster in every iteration were used to define the regimes.

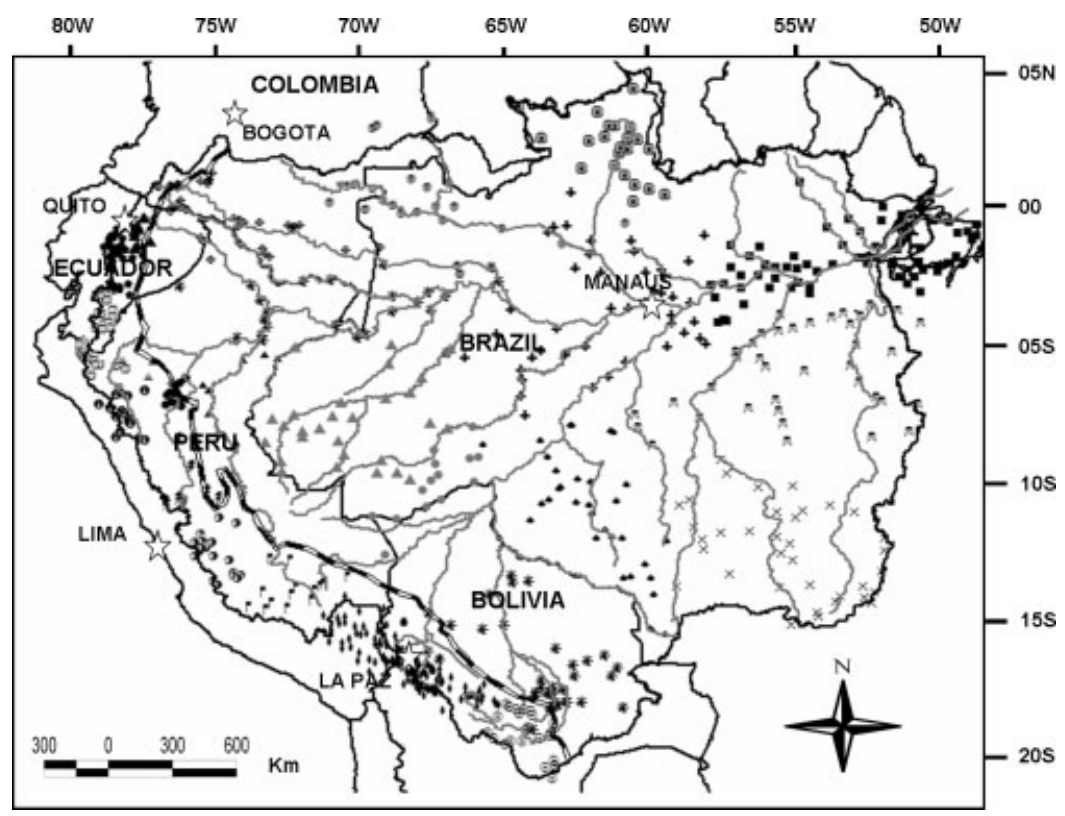

Figure 1. Limit of the Amazon basin (solid line) and of the Andean regions above $500 \mathrm{~m}$ (black and white line) and location of the rainfall gauges approved by the regional vector method (756 stations with more than 5 -year records). The 25 symbols represent the groups of stations from which the 25 vectors were created. 
To measure the average rainfall in the basin and its interannual evolution, the Kriging interpolation method is applied. This method consists in establishing a variogram for each spatial point. This variogram evaluates the influence of the 16 closest stations according to distance. The Kriging method is the only one to take into consideration a possible spatial data gradient.

Spatial and temporal structures of interannual rainfall variability are studied based on a varimax-rotated principal components analysis (PCA) (Dillon and Goldstein, 1984) on the RVM pluviometric indexes. The use of the RVM indexes rather than initial data allows long time series (1964-2003) to be considered. The applied PCA is of the varimax-type. It circumvents the exaggerated influence of variables (vectors) with a high contribution to the factors.

The analysis of rainfall trend relies on correlation coefficients; the Pearson coefficient which is parametric measures the lineal correlation among variables, whereas Spearman and Kendal coefficients are non-parametric and based on range and range probability of the data occurrence order, respectively (Kendall, 1975; Siegel and Castellan, 1988).

Breaks and changes in the series are evaluated through different methods. The Bayesian Buishand method is based on changes of the series average; the critical values for the identification of breaks are based on Monte Carlo method which remains valid even for variables with a distribution different from normal (Buishand, 1982). The Pettitt method is a non-parametric test based on changes in the average and the range of the series subdivided into sub-series (Pettitt, 1979). It is considered one of the most complete tests for the identification of changes in time series (Zbigniew, 2004). Lee and Heghinian Bayesian test uses the average as an indicator of change thanks to an a posteriori Student's distribution (Lee and Heghinian, 1977). Finally, Hubert segmentation is based on the significant difference of average and standard deviation among periods; it is particularly well-suited to the search for multiple changes in series (Hubert et al., 1989).

Geopotential, wind, and humidity data originates from the European Center for Medium Range Weather Forecast (ECMWF) (Uppala et al., 2005) reanalysis project. The ECMWF ERA-40 reanalysis data used in this study has been obtained from the ECMWF data server. Reanalysis data result from a short-term operational forecast model and from the observation of various sources (land, ship, aircraft, satellite...). Data are provided four times a day, on a $2.5^{\circ}$ latitude $X 2.5^{\circ}$ longitude global grid, at 23 pressure levels. The vertically integrated water vapour flux is derived from the specific humidity and the horizontal wind between the ground and $500 \mathrm{hPa}$ (Rao et al., 1996).

Several regional climatic indexes are used to characterize the temporal patterns resulting from the analysis of annual rainfall. The Southern Oscillation Index (SOI) is the standardized pressure difference between Tahiti and Darwin. The Multivariate ENSO index (MEI) monitors ENSO in the Pacific using sea-level pressure, zonal and meridional components of the surface wind, sea surface temperature, surface air temperature and total cloudiness fraction of the sky (Wolter and Timlin, 1993). Both indexes are from the Climatic Prediction Centre of the National Oceanic and Atmospheric Administration (CPCNOAA:http://www.cdc.noaa.gov/). Sea surface temperature (SST) data are also from the CPC-NOAA. Monthly SSTs (1950-2000) are provided for the northern tropical Atlantic (NATL, $5-20^{\circ} \mathrm{N}, 60-30^{\circ} \mathrm{W}$ ) and the southern tropical Atlantic (SATL, $0-20^{\circ} \mathrm{S}, 30^{\circ} \mathrm{W}-10^{\circ} \mathrm{E}$ ). The standardized SST difference between the NATL and SATL is computed to feature the SST gradient in this oceanic basin. The Pacific Decadal Oscillation (PDO) Index is defined as the leading component of North Pacific monthly SST variability, poleward of $20^{\circ} \mathrm{N}$ for the 1900-1993 period (Mantua et al., 1997: http://jisao.washington.edu/pdo/). When PDO is positive, water is colder in the central and western Pacific and warmer in the eastern Pacific; with a negative PDO, the reverse is observed. This negative and positive PDO 'events' tend to last from 20 to 30 years. The PDO index has been mainly positive since 1976 .

The management of the pluviometric database, as well as the application of the RVM and the calculation of the average rainfall in the basin, has been carried out using the HYDRACCESS software, developed within the framework of the HYBAM programme (free download at www.mpl.ird.fr/hybam/outils/hydraccess_en.htm; Vauchel, 2005). The calculation of changes in the series is made using the KHRONOSTAT software (free download at www.mpl.ird.fr/hydrologie/gbt/projets/iccare/khronost. $\mathrm{htm}$; IRD, 2002).

\section{Spatio-temporal rainfall variability in the Amazon basin}

Rainfall gauges approved by RVM display a heterogeneous spatial distribution in the $\mathrm{AB}$ countries (Figure 1). In Brazil, stations are evenly distributed. However, as the dense forest leads to poor access, the pluviometric stations have been mainly located along the rivers and highways. In the Andean countries there exists a great number of stations, often featuring long series, especially in mountainous regions, where access is easier than in the lowlands. On the contrary, stations are few and far between in the lowland regions of Peru, Ecuador, and Bolivia, on the border of Peru and Brazil, and in the northeast region of the basin, on the Brazilian border with Guyana and Surinam (Figure 1).

\subsection{Spatial variability of annual rainfall}

Particularly rainy regions (3000 mm/year and more) are located in the northeast, in the Amazon delta, close to the Atlantic Ocean (Figure 2), exposed to the ITCZ and in the northwest of the basin (Colombia, north of the Ecuadorian Amazon, northeast of Peru, and northwest of Brazil). Rainfall is also abundant towards the southeast, close to the average position of the South Atlantic Convergence 


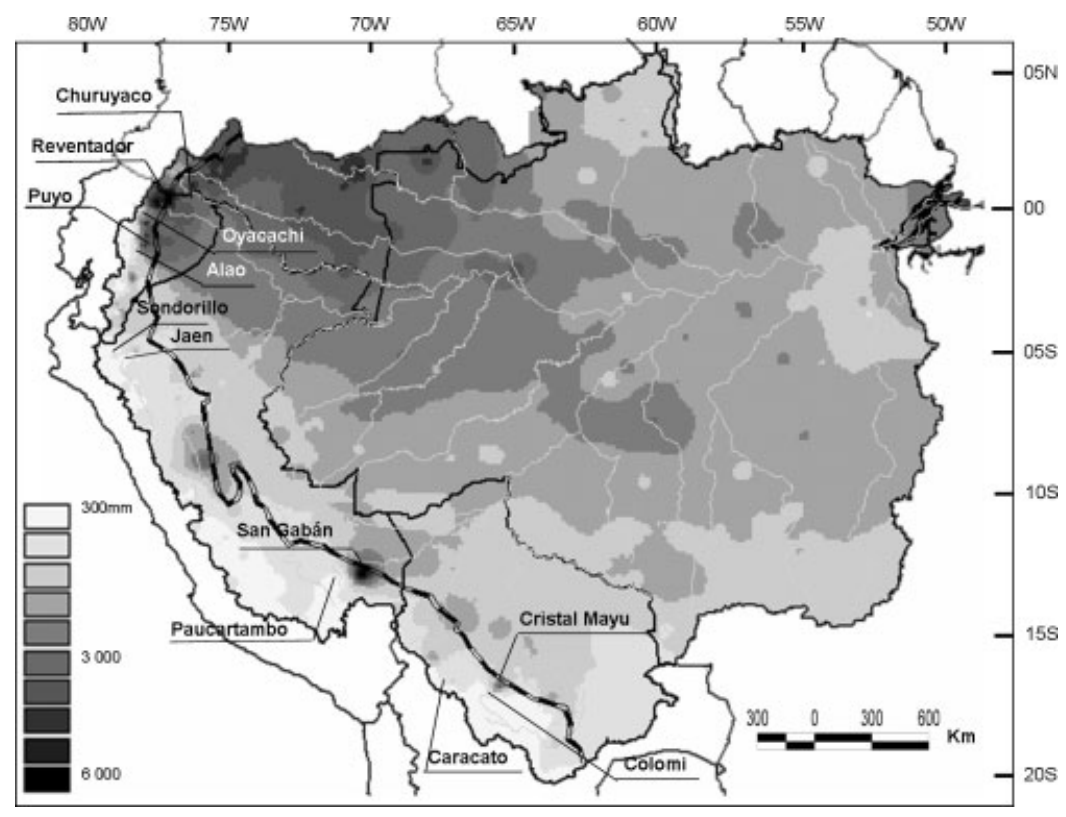

Figure 2. Mean 1975-2003 annual rain (mm/year). The pluviometric stations mentioned in the text are indicated. Andean regions above $500 \mathrm{~m}$ are limited by a black and white line.

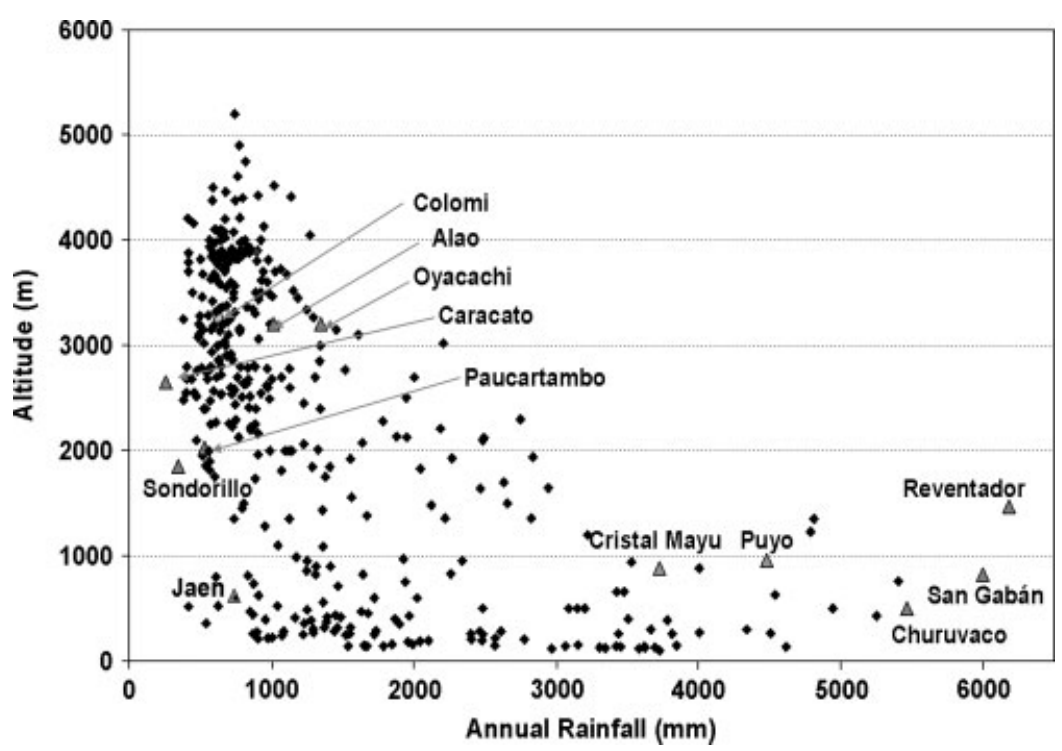

Figure 3. Relationship between altitude ( $\mathrm{m}$ asl) and annual rainfall $(\mathrm{mm})$ for the 391 stations of the Andean countries (Bolivia, Peru, Ecuador, and Colombia). The stations mentioned in the text are indicated.

Zone (SACZ), established during austral summer from the northwest of the Amazon to the Subtropical South Atlantic. Rainfall decreases towards the Tropics reaching more than $2000 \mathrm{~mm} / \mathrm{year}$ in the southeast of Brazil and less than $1500 \mathrm{~mm} / \mathrm{year}$ in the Peruvian-Bolivian plain and in the Roraima Brazilian state which is protected from the Atlantic humid flows by the Guyanese shield. This distribution is consistent with the results of Ratisbona (1976), Salati et al. (1978), Marquez et al. (1980), Figueroa and Nobre (1990), Fisch et al. (1998), and Marengo (2004), among others. However, our rainfall map yields more information about the Andean countries. Figure 2 clearly shows lower rainfall in the high Andes regions, mainly in the centre and south. Figure 3 displays the relationship between annual rainfall and altitude for 391 stations located in the Andes. Only a limited number of stations are located over $2000 \mathrm{~m}$ asl with an excess of $1500 \mathrm{~mm} /$ year and, in general less than $1000 \mathrm{~mm} / \mathrm{year}$ is measured over $3000 \mathrm{~m}$ asl. The same situation is found by Guyot (1993) and Ronchail and Gallaire (2006) in Bolivia and by Laraque et al. (2007) in Ecuador. At low elevation, abundant rainfall is related to the moist warm air and to the release of high quantity of water vapour over the first eastern slope of the Andes. The stations registering more than $3000 \mathrm{~mm} / \mathrm{year}$ are located at less than $1500 \mathrm{~m}$ asl (Figure 3). As a result, rainfall diminishes with altitude. Nonetheless, the least rainy stations such as Caracato (2650 m asl) in the Bolivian Andes with 
$255 \mathrm{~mm} / \mathrm{year}$ and Sondorillo in the Andes of northern Peru, (1850 m asl) with $345 \mathrm{~mm} / \mathrm{year}$, are not the highest (Figure 3). Indeed, the prevailing eastern direction of the moist trade winds and the exposure of the stations on the leeward side of the mountains, account for low precipitation levels measured at low altitudes. For example, little rain is registered in Jaén (620 m asl, $700 \mathrm{~mm} /$ year) which is surrounded by high mountains mainly towards the east (Figure 3 ). This is why a strong spatial variability is observed under $2000 \mathrm{~m}$ asl where rainfall varies from 500 to $3000 \mathrm{~mm} /$ year (Figure 3). Extreme values approved by the RVM analysis are in positions that favour strong air uplift, as Churuyacu (500 m asl) in Colombia with $5500 \mathrm{~mm}$, close to a steep slope and Reventador $(1470 \mathrm{~m}$ asl) in Ecuador with $6200 \mathrm{~mm}$, located on a remote volcano. Also there exists a very rainy zone in the southeast of the Peruvian Amazon. For example, San Gabán station $(820 \mathrm{~m}$ asl) gets an average of $6000 \mathrm{~mm}$ (Figure 3), and maximum values may be as high as $9000 \mathrm{~mm} /$ year (in 1967). It is located in a concavity in the Carabaya Mountain Range (south of Peru), close to steep slopes. It should also be mentioned that the RVM analysis has resulted in the rejection of several stations, particularly in very humid regions of the Andean countries. These stations located in remote areas feature scree and mudslide. As a result very scarce records have been kept. Thus, values in excess of $5000 \mathrm{~mm}$ in Chaparé, east of Cochabamba, as mentioned by Roche et al. (1990) in Bolivia, have not been included on the map (Figure 2).

Then, it is clear that the highest and lowest annual rainfall values in the $\mathrm{AB}$ are registered in the Andean region (Figures 2 and 3). Some cases illustrate the high spatial rainfall variability. In Ecuador, the Reventador station (1470 m asl; $6200 \mathrm{~mm}$ ) is $80 \mathrm{~km}$ from Oyacachi (3200 m asl) whose annual rainfall is $1400 \mathrm{~mm}$; the spatial variation between both stations is thus $58 \mathrm{~mm} / \mathrm{km}$. Also, between Puyo (960 m asl, with $4500 \mathrm{~mm}$ ) on the border of the Andes, and Alao $(3200 \mathrm{~m}$ asl, with $1000 \mathrm{~mm}$ ) situated in an embanked valley, at a distance of $55 \mathrm{~km}$, there is a $63 \mathrm{~mm} / \mathrm{km}$ difference. In Peru, San Gabán $(820 \mathrm{~m}$ asl; $6000 \mathrm{~mm})$ is $110 \mathrm{~km}$ from Paucartambo $(2030 \mathrm{~m}$ asl, with $530 \mathrm{~mm})$. It is situated in a valley behind the Carabaya Mountain Range. In this case there is a $50 \mathrm{~mm} / \mathrm{km}$ difference between both stations. In Bolivia, Cristal Mayu (880 m asl, with $4000 \mathrm{~mm}$ ) is located $46 \mathrm{~km}$ away from Colomi $(3280 \mathrm{~m}$ asl and $630 \mathrm{~mm}$ ); the difference is still higher, $73 \mathrm{~mm} / \mathrm{km}$. The preceding examples show the important role of relief in determining the annual rainfall (Figure 3).

\subsection{Seasonal cycle}

The seasonal cycle is assessed with maps showing the quarterly percentage of rainfall (Figure 4) and using the AHC and K-means cluster analysis based on monthly rainfall indexes (Figure 5). AHC analysis enables the definition of an optimum number of nine clusters corresponding to nine regimes and the K-means technique gathers together stations experiencing the same regime. The seasonal cycle is also described using quarterly maps showing the mean 1979-1998 geopotential height at $850 \mathrm{hPa}$ and the vertically integrated water vapour transport (Figure 6).

Figure 5(a) and (c) evidence a clear opposition between the tropical northern and southern regions of the Amazon in austral summer (DJF) and austral winter [June-JulyAugust (JJA)]. In JJA the percentage of annual rainfall

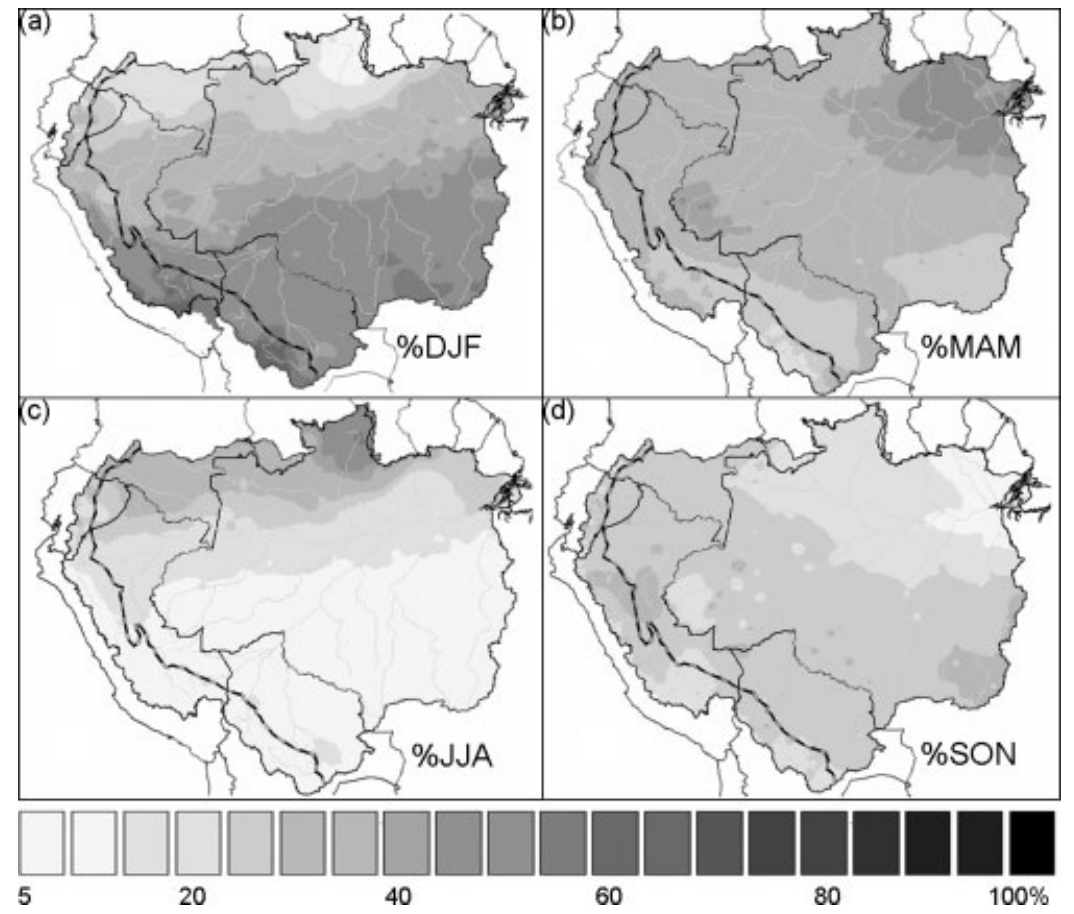

Figure 4. Quarterly percentages of rainfall (\%) in (a) December-January-February (DJF), (b) March-April-May (MAM), (c) June-July-August (JJA), and (d) September-October-November (SON). The Andean regions above $500 \mathrm{~m}$ are limited by a black and white line. 

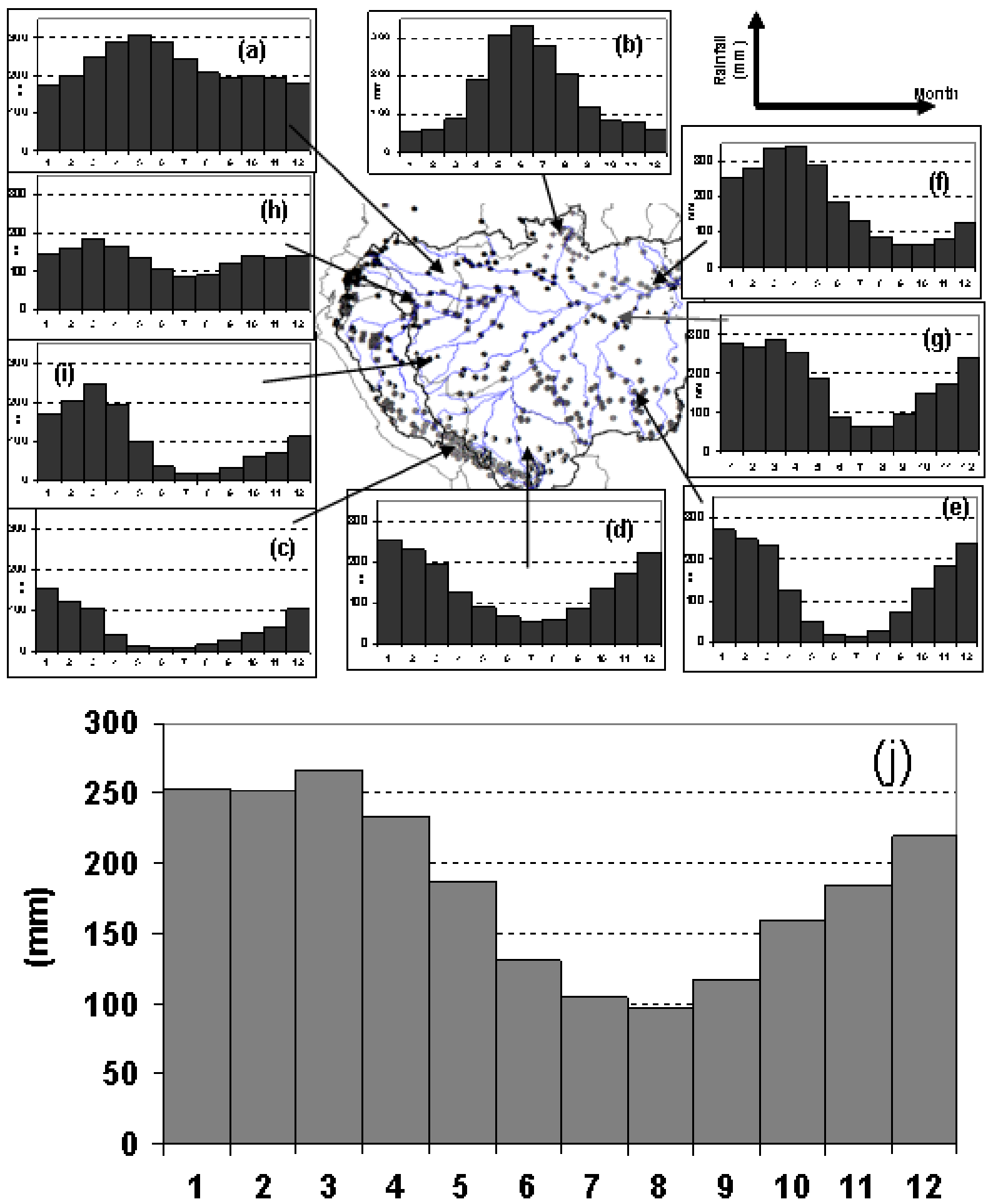

Figure 5. (a)-(i) Annual regimes, resulting from AHC and K-means classifications on a monthly rainfall index in 756 stations. Each symbol on the map corresponds to a regime. Each graph represents the average monthly rainfall of all the stations belonging to a class. (j) Annual regime of the average 1975-2003 rainfall in the Amazon basin at the delta. This figure is available in colour online at www.interscience.wiley.com/ijoc

is over $50 \%$ in the northern region (north of Brazil and Colombia), and below $20 \%$ in the south (south of Brazil, Peru, and Bolivia). The opposite is true in summer (DJF). Tropical regimes are also depicted in Figure 5(b) (Northern Hemisphere tropical regime) and in Figure 5(c)-(e) (Southern Hemisphere tropical regimes). In the Northern Hemisphere, particularly in the State of Roraima (Brazil), the rainfall peak in JJA is related to the warming of the continent and of the tropical Atlantic and eastern Pacific Ocean surface temperature (Pulwarty et al., 1998). To the south, the rainy season in austral summer is related to continent warming ( $\mathrm{Fu}$ et al., 1999), to a low geopotential height in the Chaco region and to the onset of the South American monsoon (SAMS) and the related low-level jet (LLJ) along the Andes (Figure 6(a); Zhou and Lau, 1998; Saulo et al., 2000; 


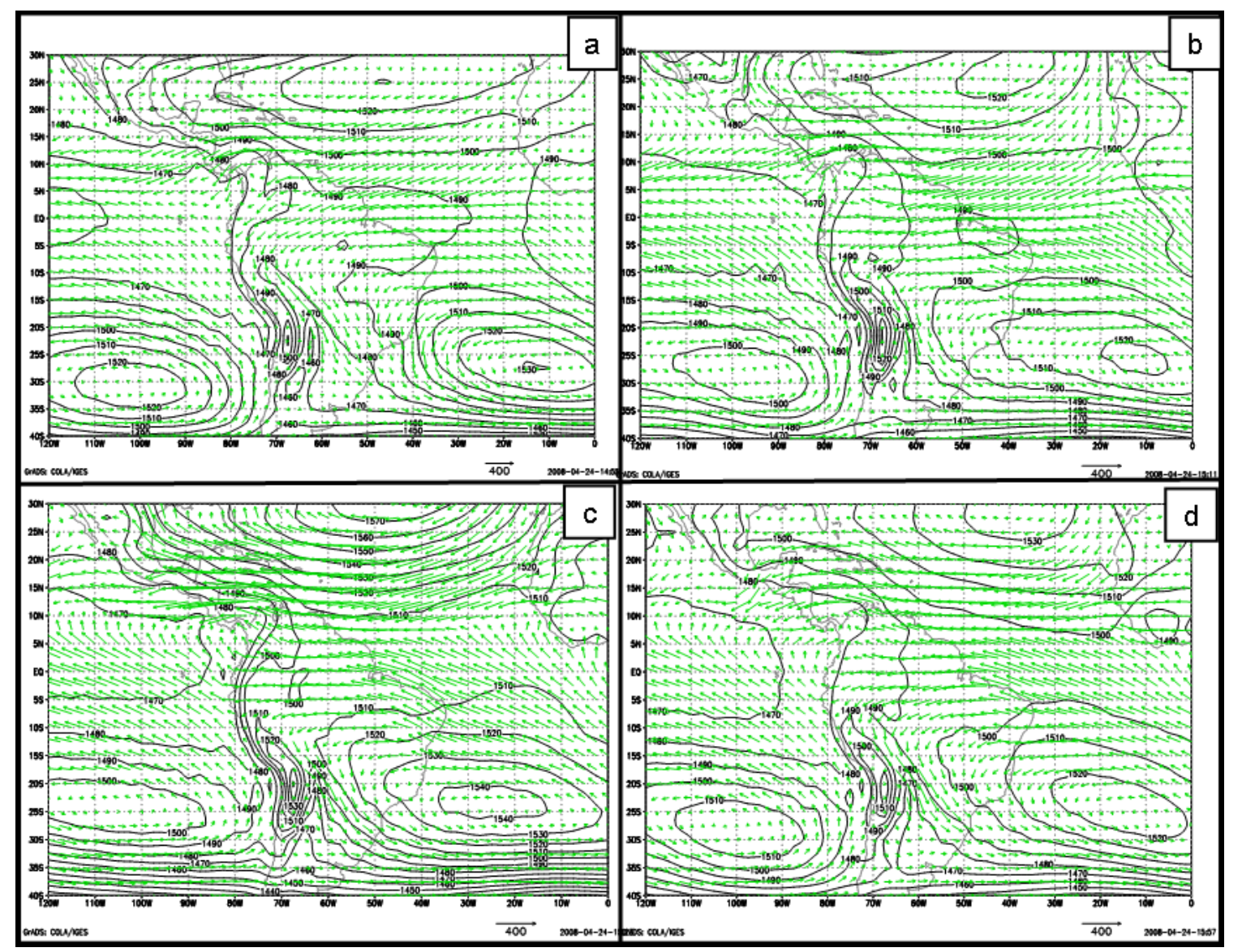

Figure 6. Mean 1964-2002 $850 \mathrm{hPa}$ geopotential height $(\mathrm{m})$ and vertically integrated water vapour flux $(\mathrm{kg} / \mathrm{m} / \mathrm{s})$ between the ground and $500 \mathrm{hPa}$ wind in (a) January, (b) April, (c) July, and (d) October. The figures use ECMWF data. This figure is available in colour online at www.interscience.wiley.com/ijoc

Marengo et al., 2004). On the contrary, the dry season in JJA is related to high geopotential height values and to the retreat of the SAMS (Figure 6(c)). In the south, tropical regimes differ according to the length of the dry season. In the tropical Andes, it lasts from May to September (Figure 5(c)); only 5\% of the annual rainfall can be registered during this period. In the lowlands the dry season is shorter, lasting from June to August. In the Bolivian plain the dry season is rainier (Figure 5(d)) than in the Mato Grosso (Figure 5(e)). This is because extratropical perturbations skim through the Bolivian lowlands during winter (Figure 6(c)) (Oliveira and Nobre, 1986; Ronchail, 1989; Garreaud, 2000; Seluchi and Marengo, 2000).

In the northeastern $\mathrm{AB}$, autumn [March-April-May (MAM)] and spring (SON) are the most different seasons (Figure 4(b) and (d), respectively); more than 50\% of annual rainfall can be measured in MAM, whereas less than $10 \%$ occurs in SON. This 'tropical maritime' regime involves a region from the Amazon delta to approximately $1000 \mathrm{~km}$ in the centre of the basin, at the confluence of the Amazon and Madeira River (Figure 5(f)). In this region, seasonality is mainly controlled by the Atlantic Ocean. In particular, the precipitations peak in austral autumn is related to the heating of the equatorial Atlantic and to the southernmost position of the ITCZ (Fu et al., 1999; Fu et al., 2001). On the contrary, in austral spring, the dry season is associated with the northward shift of warm waters and of the ITCZ.

In the northwest of the basin, in regions close to the equatorial line, rainfall distribution over the year is more uniform, with percentages close to $25 \%$ during each quarter (Figure 4). In Ecuador, the very low rainfall seasonality is related to deep convection on the always warm surface (Fu et al., 1999) and to the geopotential height that is very low from austral spring to austral autumn (Figure 6(b)). However, two different regimes can be highlighted from the upper Negro basin to the lowlands of Ecuador; on the windward slopes of the Andes, a unimodal regime with a slight peak at the end of the austral autumn (Figure 5(a)) is due to enhanced convection after the equinox and to a strong zonal water vapour transport (Figure 6(b)) (Laraque et al., 2007). A bimodal regime, with peaks near the equinoxes (April and October) and a slight decrease in austral winter is depicted in the intra-Andean basins in Peru and Ecuador, and in the Amazon plain, on the border of Peru, Brazil, and Colombia (Figure 5(h)). The semi-annual rainfall cycle results from the zonal oscillation of the continental ITCZ, associated with the semi-annual cycle of radiation and temperature (Horel et al., 1989; Figueroa and Nobre, 1990; Poveda, 2004; Poveda et al., 2006). 


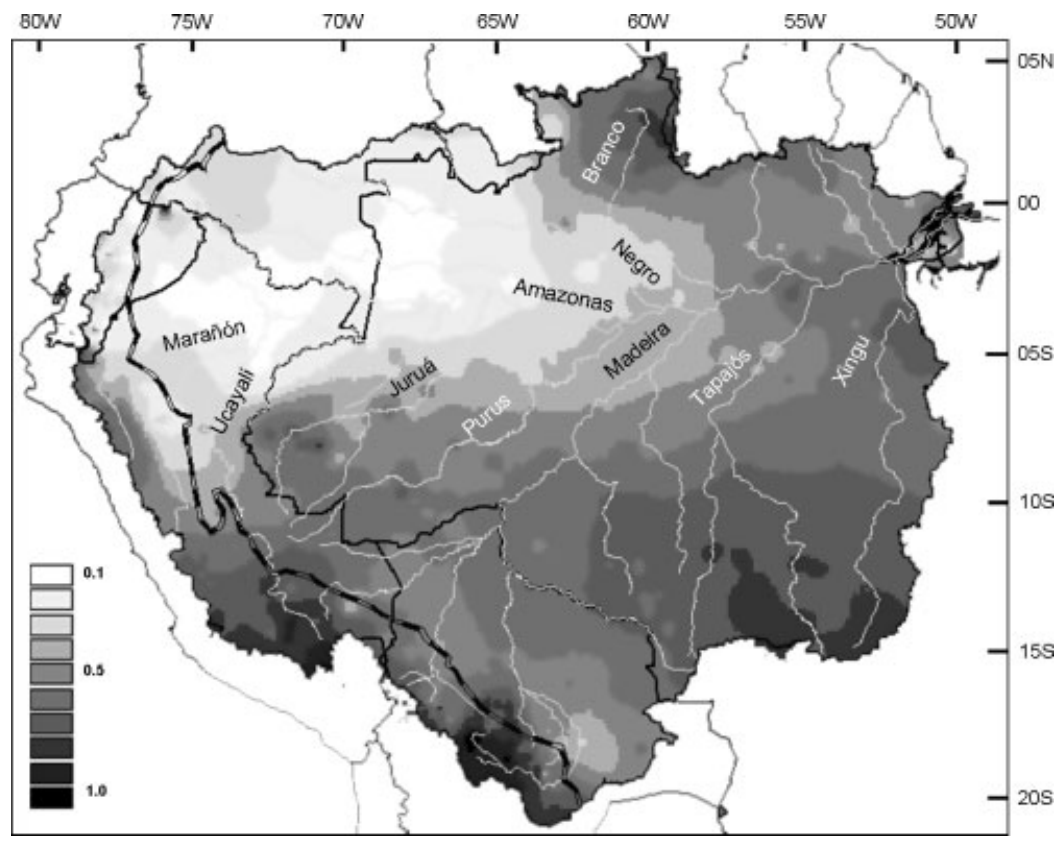

Figure 7. Seasonal variability coefficient (sVC): coefficient of variation computed on mean 1975-2003 monthly rainfall values. The Andean regions above $500 \mathrm{~m}$ are limited by a black and white line. The rivers mentioned in the text are named.

Finally, transition regimes prevail between 5 and $10^{\circ} \mathrm{S}$. In the central and eastern regions of the basin, an intermediate regime, between southeast (Figure 5(e)) and northeast (Figure $5(\mathrm{f})$ ), is characterized by a rainy period from December to April (Figure 5(g)). In Peru, in the plain and the Andes, an intermediate regime between the southern tropical regime (Figure 5(c) and (d) and the northern bimodal regime in the north (Figure 5(h)), features a rainier season in March and a dry season from June to September (Figure 5(i)).

These results are similar to those described in previous studies for Brazil (Ratisbona, 1976; Salati et al., 1978; Kousky et al., 1984; Horel et al., 1989; Nobre et al., 1991; Marengo, 1992; Zhou and Lau, 2001; Ronchail et al., 2002). However new pieces of information are provided for the Andean regions, which had remained poorly documented.

The sVC (Figure 7) shows the important seasonal variability of rainfall with values over 0.6 in inner and tropical Andean regions, in the southern Andes of Peru (in the region of Apurimac, in the upper Ucayali basin) and in southwestern Bolivia (in the region of Sucre, in the upper Mamore Basin). From the south of the Bolivian lowland to southern Peru, in a corridor between the Andes and the Brazilian shield, the relatively low seasonal variability is due to winter rainfall related to extra-tropical perturbations. A strong sVC may be noticed in other tropical regions of the basin, particularly in the southeast (Mato Grosso) and in the north of Brazil (Roraima). In the northeast of the basin, close to the Amazon delta, there is also a major seasonal variation with an $\mathrm{sVC}$ value in excess of 0.5 . Between $5^{\circ} \mathrm{N}$ and $5^{\circ} \mathrm{S}$, a strong decrease in sVC is observed from $60^{\circ} \mathrm{W}$ towards the west, with values under 0.1 , mainly in the lowland forests of Peru and Colombia and in the west of the Brazilian
Amazon (Figure 7). This evidences the constant presence of rainfall in this region, confirming what is shown in Figures 4 and 5(a) and (h). In the northern part of Peru, there is an important east-west increase in $\mathrm{sVC}$ between the Amazon plain and the regions close to the Andes, as well as between the north and the south (throughout the Ucayali basin).

The Amazon basin of Peru and Ecuador down to Tamshiyacu $\left(4.00^{\circ} \mathrm{S}\right.$ and $\left.73.16^{\circ} \mathrm{W}\right)$ extends over a surface of $726400 \mathrm{~km}^{2}$, with $53 \%$ over $500 \mathrm{~m}$ asl (Mialocq et al., 2005 and Espinoza et al., 2006). It experiences a high spatial variability of annual rainfall regimes (Figure 8).

The southern part of the basin displays a clear south tropical regime with a long dry season from May to September, such as Antabamba station $\left(14.37^{\circ} \mathrm{S} 72.88 \mathrm{~W}\right.$; $3900 \mathrm{~m}$ asl, Figure 8(a)), with an annual cycle beginning in August and a rainy period from December to March. In the upper basin of the Huallaga and Ucayali Rivers, a tropical humid regime at Quillabamba station $\left(12.86^{\circ} \mathrm{S}\right.$ $72.69^{\circ} \mathrm{W} ; 1128 \mathrm{~m}$ asl, Figure 8(b)) features a much longer and intense rainy period (from December to May). At Pozuzo $\left(10.05^{\circ} \mathrm{S} 75.55^{\circ} \mathrm{W} ; 258 \mathrm{~m}\right.$ asl $)$ in the north, at a lower altitude, a higher rainfall value and a shorter dry period (JJA) is observed (Figure 8(c)). In the north, in the upper Marañón River (Figure 8(d)), an intermediate regime between southern Tropics and the equator features a very rainy period from January to April, as in Julcán station $\left(8.05^{\circ} \mathrm{S} 78.50^{\circ} \mathrm{W} ; 3450 \mathrm{~m}\right.$ asl). In the regions close to the equatorial line, longer rainy seasons are noticed; for example, the Gualaquiza station $\left(3.40^{\circ} \mathrm{S} 78.57^{\circ} \mathrm{W} ; 750 \mathrm{~m}\right.$ asl, Figure $\left.8(\mathrm{e})\right)$ close to the Andes presents a rainy season from February to July and no dry period. Towards the east in Iquitos $\left(3.75^{\circ} \mathrm{S}\right.$ $73.25^{\circ} \mathrm{W} ; 125 \mathrm{~m}$ asl, Figure $8(\mathrm{f})$ ), a more uniform regime 


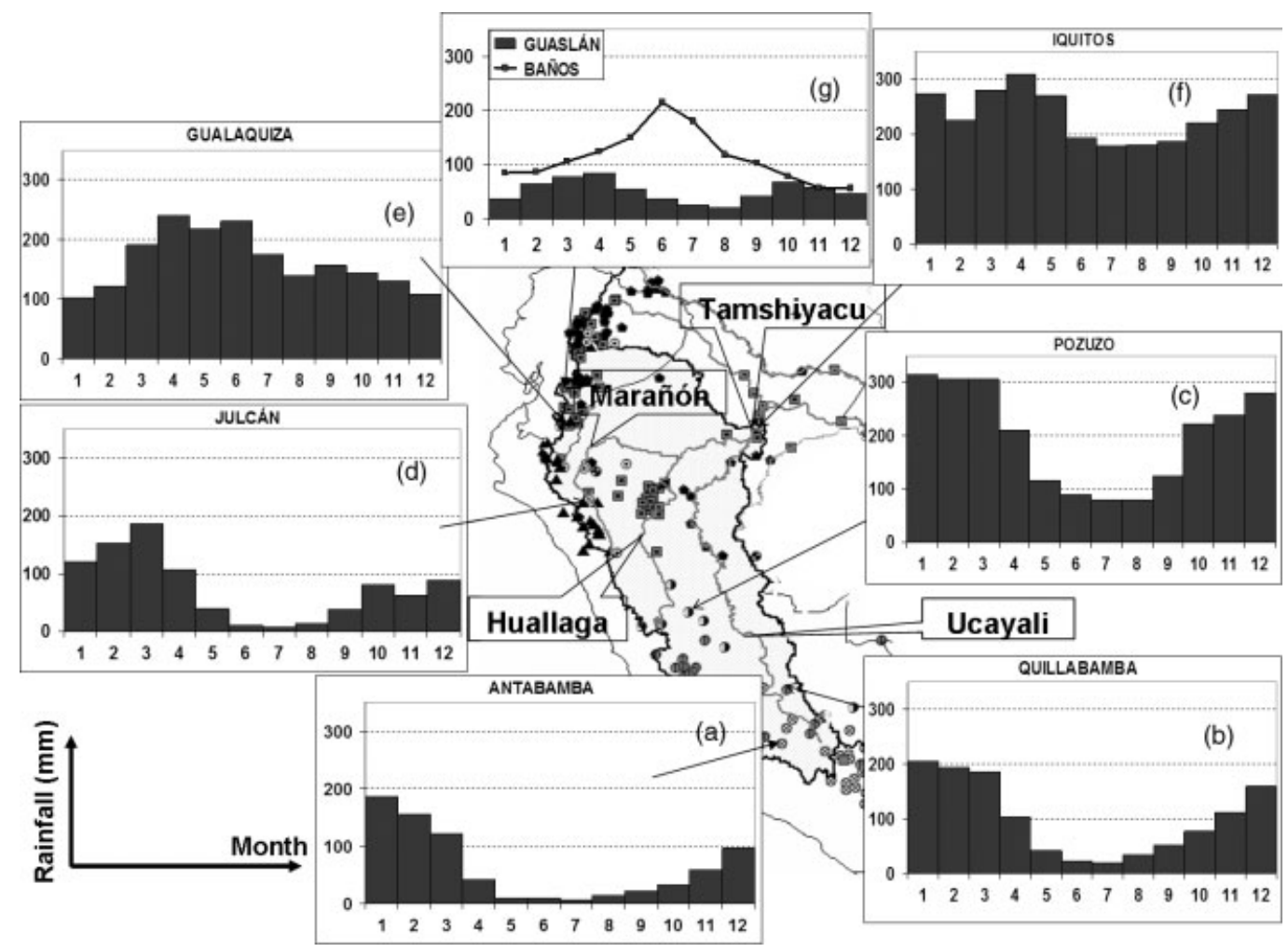

Figure 8. Rainfall regimes in eight stations in the Peruvian and Ecuadorian Amazon basin. Each symbol on the map corresponds to a regime as in Figure 5. The main rivers are named.

is depicted with a slight rainfall decrease from June to September, and a very weak sVC, as shown in Figure 7.

The spatial variability of rainfall regimes may be even greater as shown in studies about Ecuador. Stations with different regimes coexist in the same basin because of their different exposures to the easterlies. For example the minimum rainfall in Guaslan, in an intra-Andean basin, coincides with the rainfall peak in Baños, located on a windward slope (Figure $8(\mathrm{~g})$ ). This is due to an increase in the water vapour transport, in austral winter, which causes rainfall peaks in windward stations (Laraque et al., 2007; Bendix, Personal Communication).

The average monthly rainfall calculated for the whole AB (Figure 5(j)) presents a rainy period from December to April (between 220 and $270 \mathrm{~mm} / \mathrm{month}$ ) and less rainfall from July $(105 \mathrm{~mm})$ to August $(95 \mathrm{~mm})$. The sVC (0.34) is low and shows the influence of the northwest region, which, although not so extended, is very rainy and exhibits a low seasonality (Figures 2 and 5). Nevertheless, this rainfall cycle, with a drier season in winter, also reflects the influence of the extended southern tropical regions, from $5^{\circ} \mathrm{S}$ to the south of the basin, characterized by a marked dry season around July and August (Figure 5).

\subsection{Interannual variability}

The interannual rainfall variability resulting from the iVC is particularly important in the mountainous regions of the Andean countries (Figure 9(a)), in the Tropics (Chaco and Roraima) and close to the Amazon delta.
High values of iVC are also found on the elevated border of Peru and Brazil (Fitzcarrald Arch, 400-500 m asl, upper Juruá and Purus Rivers, see Figure 9(a)). Regions with lower interannual variability are situated along the northwest-southeast axis of the $\mathrm{AB}$, where rainfall is abundant. Isolated high values may be related to particular local conditions.

The interannual-seasonal variability ratio (iVC/sVC) highlights a major uniformity of rainfall distribution during the year in the western equatorial regions of the $\mathrm{AB}\left(0^{\circ}-05^{\circ} \mathrm{S}\right.$ and $\left.65^{\circ}-77^{\circ} \mathrm{W}\right)$ (Figure $\left.9(\mathrm{~b})\right)$. In this region, interannual variability is three times higher than seasonal variability (iVC/sVC up to 3.0). On the contrary, in the south and east of the Amazon, seasonal variability exceeds interannual variability.

Interannual variability is also addressed using a varimax-rotated PCA on rainfall index vectors resulting from the RVM analysis. On the one hand, the advantage of this procedure lies in the use of data summarizing the interannual variability of homogeneous zones already specified by the RVM. Thus, 25 different regions are defined, from which 9 belong to the Brazilian Amazon plain and 16 are located in the Andean countries (Figure 1). In Brazil, regionalization is similar to that found by Hiez et al. (1991). On the other hand, the use of annual pluviometric indexes from RVM allows the analysis period to be extended to 1964-2003 (see Chapter 2).

PCAs are computed on a quarterly rainfall, i.e. DJF, MAM, JJA, and SON. The first three components of 

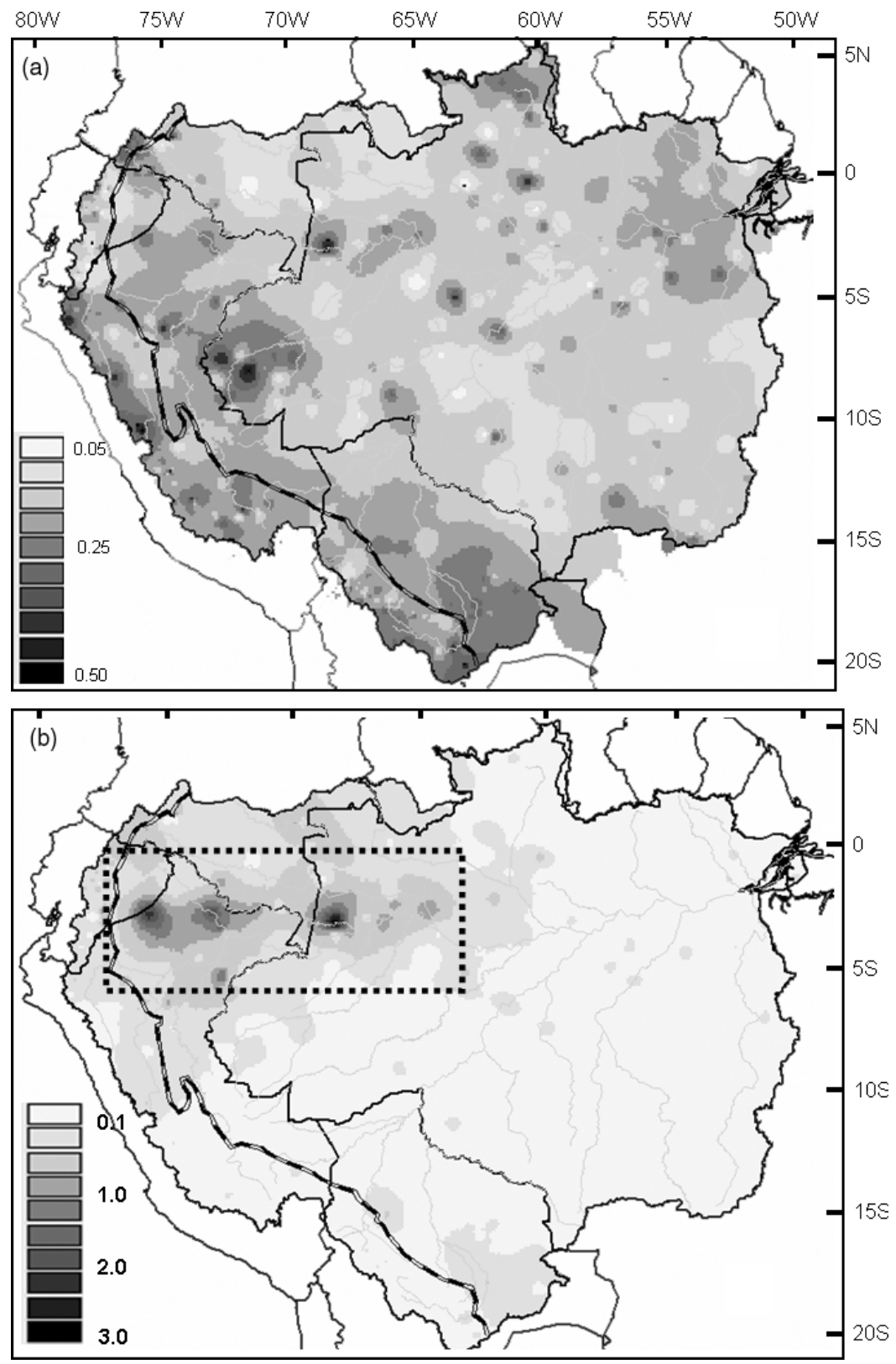

Figure 9. (a) Interannual variability coefficient (iVC): coefficient of variation of annual 1975-2003 rainfall. (b) Ratio between the interannual variability coefficient and the seasonal variability coefficient. In the dotted rectangle is the region where the interannual variability is more important than the seasonal variability. The Andean regions above $500 \mathrm{~m}$ are limited by a black and white line.

the PCAs generally summarize $45-50 \%$ of total rainfall variability.

In JJA and SON, experiencing little rainfall except in the northwest, the main variability is pluridecadal, with a change at the end of the 1970s in JJA (Figure 10) and the beginning of the 1980s in SON (not shown). The first principal components (PCs) account for 26 and $18 \%$ of the explained variance in JJA and SON, respectively. High rainfall is registered during the first period in the whole $A B$. The signal is very strong in the northwest, whereas it is weak in the south. Low rainfall characterizes the second period. We use the ERA-40 reanalysis to take into account the differences in atmospheric circulation between both periods. Figure 11(a) displays the differences in the $850 \mathrm{hPa}$ geopotential height and wind between 1986-1997, the driest period, and 1967-1976, the rainiest period. After the 1970s, an enhanced geopotential height can be observed over the western Amazon and the tropical Atlantic. Water vapour diverges from these regions leading to a reduced rainfall. Interestingly, as a low geopotential height prevails over eastern Brazil, water vapour converges towards this region (Figure 11(b)). Given the fact that El Niño events are related to dryness in northern Amazon and that a strong frequency of El Niño events has been observed since the end of the 1970s (Trenberth and Hurrell, 1994), it is assumed that the rainfall decrease in the north of the basin after that date can be attributed to the warming of the tropical Pacific. The time series of the first PC in JJA is negatively correlated with the JJA multivariate 

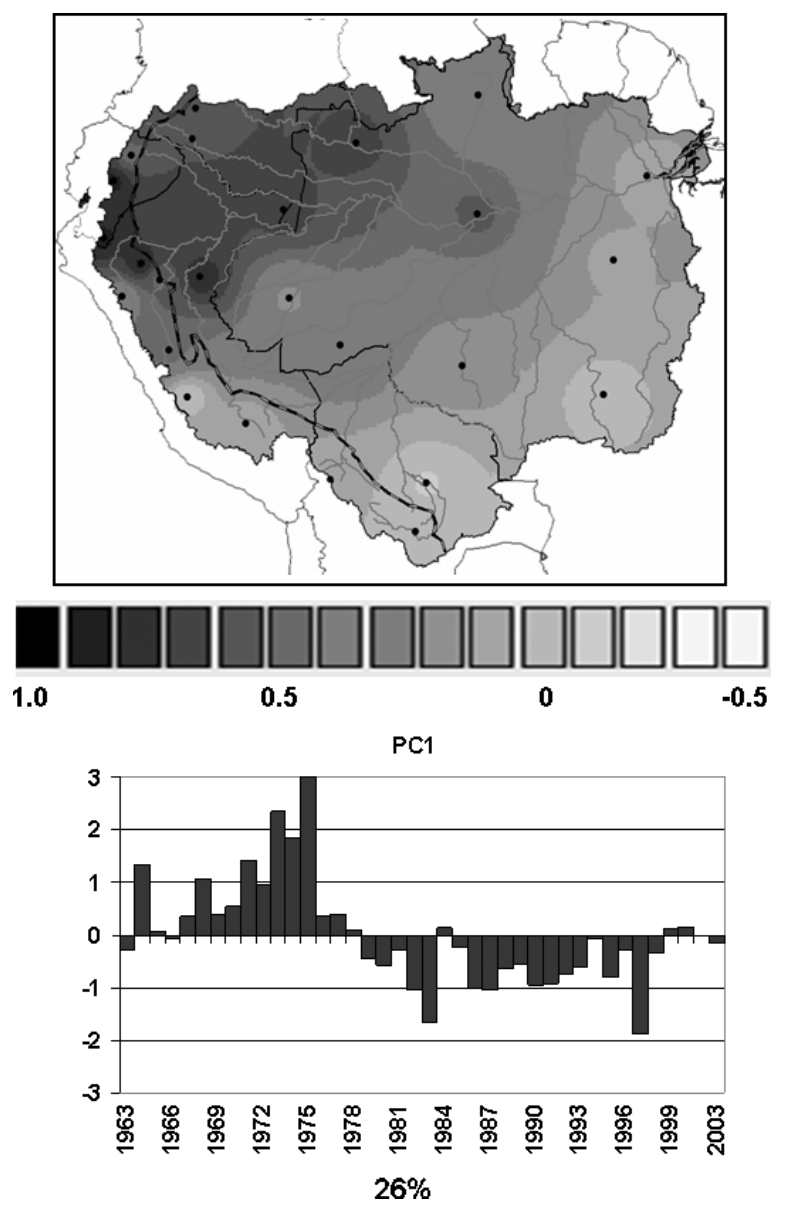

Figure 10. Spatial and temporal patterns associated with the first principal component resulting from a PCA analysis on JJA rainfall in 25 vectors (part 2).

ENSO index (MEI) and PDO indexes $(r=-0.69$ and -0.66 , respectively, both correlations being significant at the 99\% level; Figure 12). Partial correlations show that both indicators combine to account for $65 \%$ of the total rainfall variance. At an interannual time scale, positive MEI values are associated with very low rainfall over the basin $(1983,1997)$, whereas negative MEI values are concomitant with high rainfall $(1973,1975)$. At a pluriannual time scale, low PDO values during the 1960s and 1970s are associated with high rainfall. The opposite can be observed during the 1980s and 1990s. Marengo (2004) and Marengo et al. (2008) already mentioned connections between the long-term rainfall variability in the $\mathrm{AB}$ and the PDO.

The aforementioned long-term variability is also present in MAM and DJF seasons and but it is not the main mode of variability. Pluriannual variability in DJF and MAM, the rainiest seasons in many regions (Figure 5), is observed at a decadal time scale. PC1 in DJF (27\% of variance) and PC2 in MAM (16\%) show the same time space modes of variability. In MAM, rainfall is important (weak) in the northwest (southeast) of the basin during the 1970s and 1990s, and the opposite can be noticed from the beginning of the 1980s till the beginning of the 1990s with a higher than normal rainfall in the southeast (Figure 13). The rainfall increase in southeastern Amazon at the end of the 1970s is related to a negative geopotential height (Figure 14(a)) over southern Amazon where there is an intensification of the northwest wind along the Andes and of the LLJ and to the convergence of water vapour from the Atlantic and northwest Amazon (Figure 14(b)). On the contrary, stronger than normal geopotential height prevails over northwestern Amazon where water vapour diverges. The rainfall increase in northwestern Amazon during the last decade is related to a reduced northwest wind and LLJ and to an increased water vapour convergence over the north (Figure 14(d)), promoted by a positive geopotential anomaly over most of the continent south of the equator line (Figure 14(c)). In DJF and MAM, the PC loadings are very weakly correlated to the PDO $(r=-0.38$, $p>0.95$ in MAM). These results are consistent with Ronchail (1996) who finds a similar pluriannual variability in Bolivia and with Marengo and Nobre (2001) and Marengo (2004) who show opposite long-term evolutions in the north and south of the Brazilian AB. Also Lau and Wu (2006) describe a similar spatio-temporal pattern, with an increase in the annual rainfall along the tropical Andes, whereas the annual rainfall decreases in the eastern and southern parts of the Amazon, between 1979-1990 and 1991-2002. However, our study yields some insights into the seasonality of the pluriannual rainfall evolution.

In DJF and MAM, an interannual variability represented by PC2 in DJF and PC3 in MAM accounts for 13 and $10 \%$ of rainfall variance, respectively (Figure 15). Strong positive values are displayed during the 1970s, in 1984-1985-1986, 1989, and 1995 (many of them La Niña years), and negative values in 1983, 1992-1993, and 1998 (most of them El Niño events). An opposition is pointed out between, on the one hand, the south of the Andean region (Peruvian and Bolivian Altiplano) and the northeast (in DJF) and east (in MAM) of the $\mathrm{AB}$, and on the other, the southeast of the basin in DJF (the southwest in MAM) and the northwest of the $\mathrm{AB}$. The two PCs are related to the interannual variability of ENSO and of the SST gradient between the NATL and the SATL (Figure 16). Correlation values between the DJF and MAM PCs and the seasonal MEI are -0.55 (significant at the $99 \%$ level), indicating that during El Niño events, rainfall is less abundant in the tropical Andes and in the east of the $\mathrm{AB}$, as already described by Kousky et al. (1984), Aceituno (1988), Marengo (1992), Marengo and Hastenrath (1993), Moron et al. (1995), Ronchail (1998), Liebmann and Marengo (2001), and Ronchail et al. (2002), among others. El Niño events are associated with a rising motion over the eastern regions of the equatorial Pacific Ocean and subsidence over the northern AB (Kousky et al., 1984). Additionally, Garreaud and Aceituno (2001) show that the northward position of the Bolivian High during El Niño events prohibits the uplift of moist air towards the Altiplano, preventing rainfall in this region. On the contrary, rainfall tends to be slightly more abundant during El Niño events in western and 
(a) JJA $850 \mathrm{hPo}$ Wnd-Hgt 1986-1997 minus 1967-76

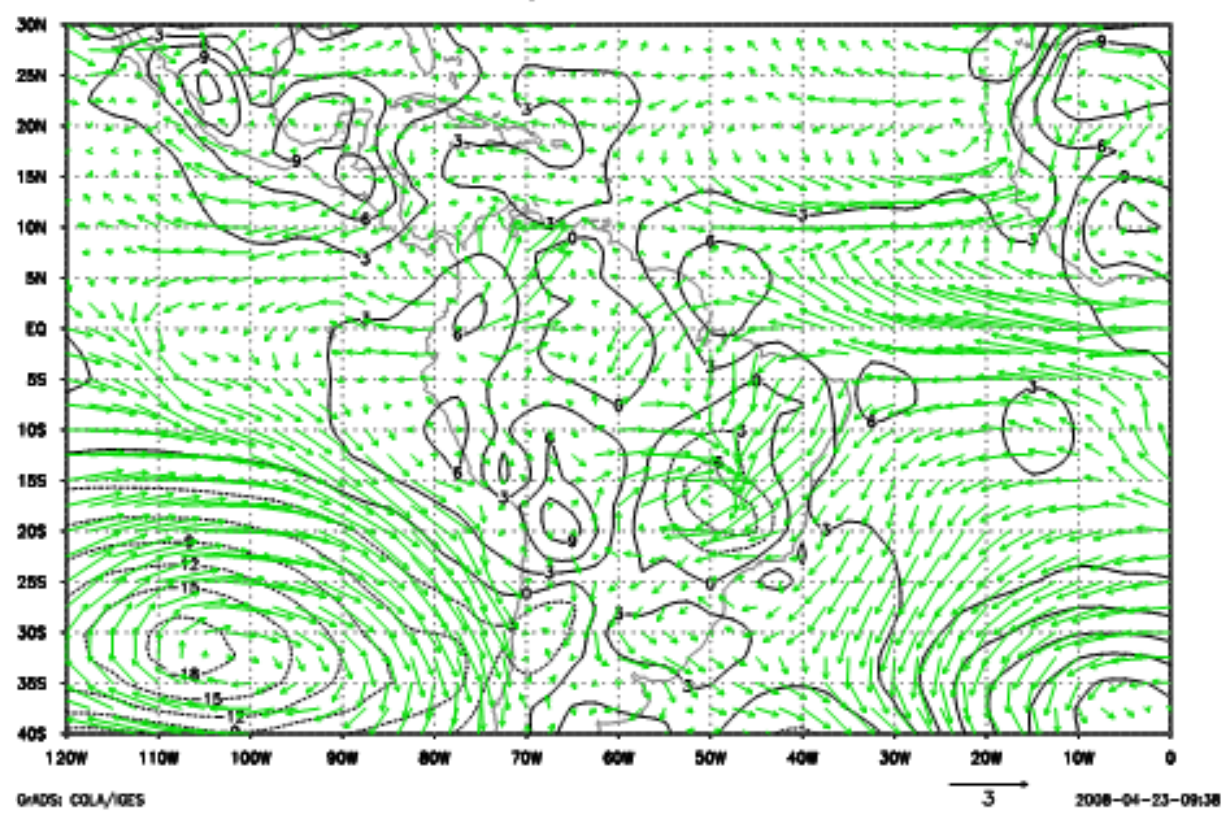

(b)

JJA WVT 1986-97 minus 1967-76

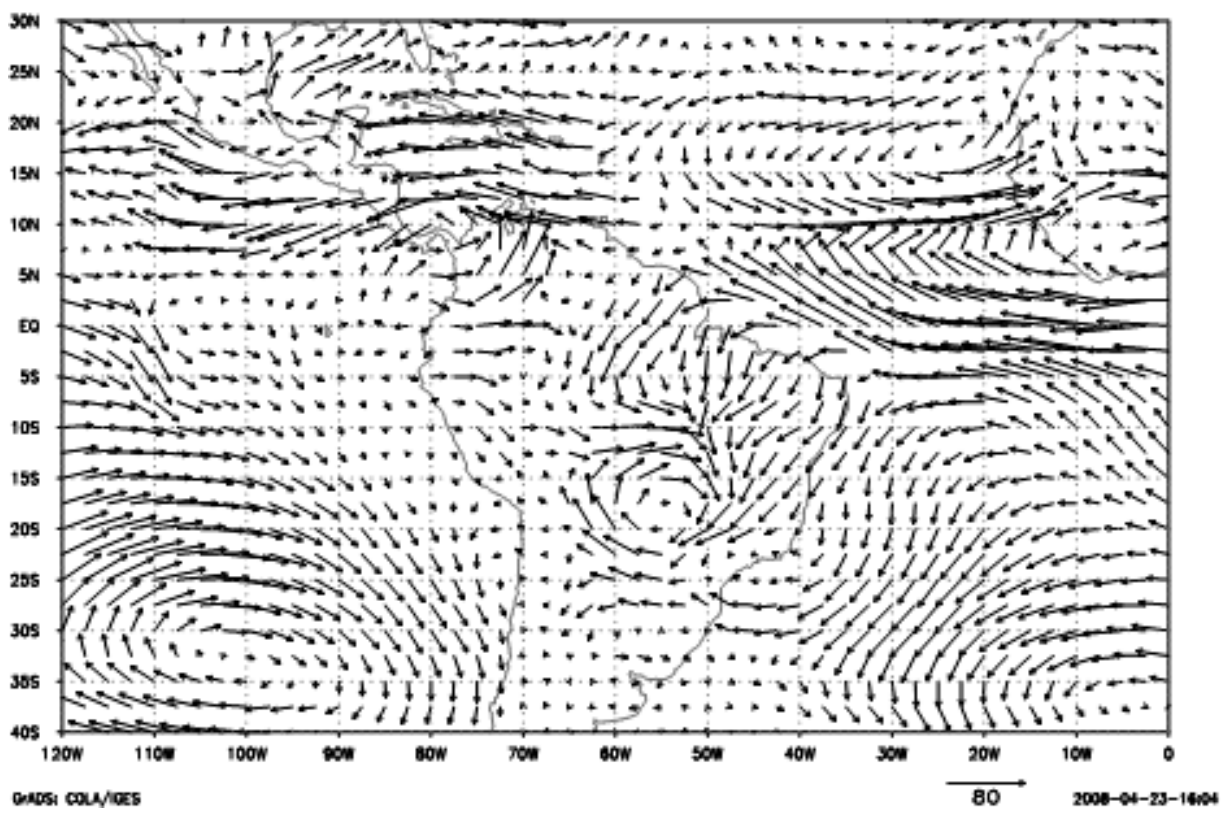

Figure 11. JJA differences between 1986-1997 and 1967-1976 in (a) $850 \mathrm{hPa}$ geopotential height (m) and wind (m/s), (b) vertically integrated water vapour flux $(\mathrm{kg} / \mathrm{m} / \mathrm{s})$ between the ground and $500 \mathrm{hPa}$. The figures use ECMWF data. This figure is available in colour online at www.interscience.wiley.com/ijoc

southern Amazon, as reported by Ronchail (1998), Ronchail et al. (2002, 2005), Bendix et al. (2003), Grimm (2003, 2004), and Ronchail and Gallaire (2006).

The correlation between these PCs and the annual difference between the northern and SATL SSTs is also significant at the $99 \%$ level $(r=-0.59$ in DJF and $r=$ -0.48 in MAM). Figure 16 shows that when this gradient is positive, i.e. when the north tropical Atlantic is warmer and/or the south tropical Atlantic is colder than usual, rainfall is less abundant in the northeast of the basin, as previously pointed out and explained by Molion (1987, 1993), Marengo (1992), Moron et al. (1995), Nobre and
Shukla (1996), and Ronchail et al. (2002), among others. Tropical Atlantic Ocean warming causes a rising motion over this ocean and subsidence in the south of the $A B$, a shift to the north of the ITCZ and less rainfall over northeastern Amazon. The opposite can be noticed when the Atlantic SST gradient is negative.

The partial correlations between, on the one hand, PC2 in DJF and SOI or MEI and NATL-SATL on the other, are significant, indicating that both climatic indicators are complementary to account for interannual variability. Together they make up $50 \%$ of rainfall variability as described by PC2 in DJF. 


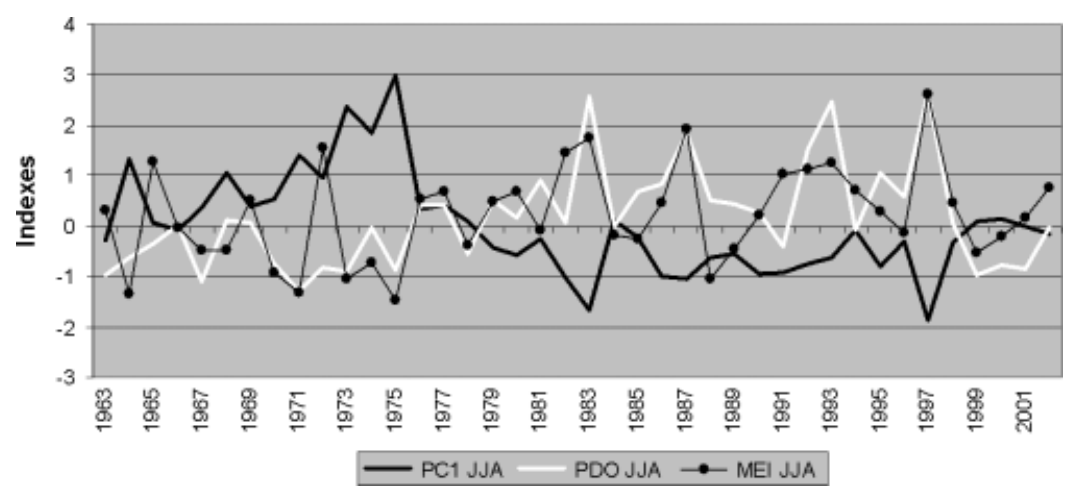

Figure 12. 1963-2003 time evolution of the first PC of a PCA analysis on JJA rainfall and JJA PDO and MEI indexes.
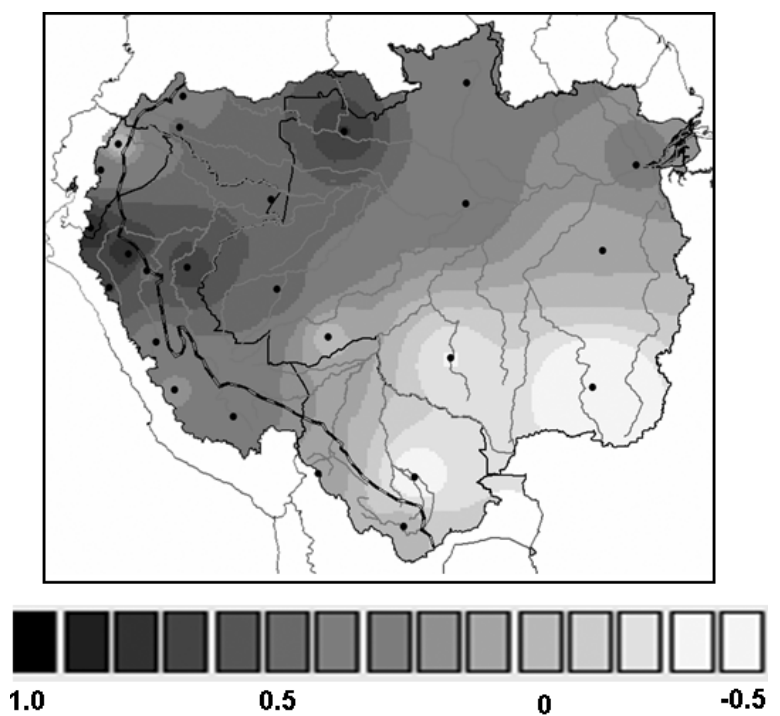

PC2

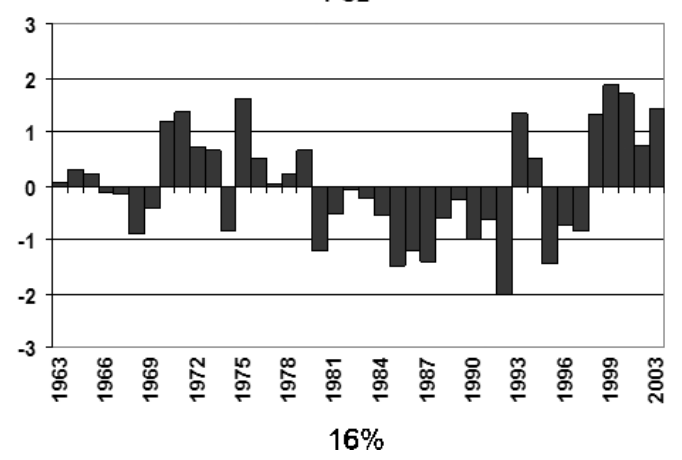

Figure 13. Spatial and temporal patterns associated with the second principal component resulting from PCA analysis on MAM rainfall in 25 vectors (part 2).

\subsection{Mean rainfall in the basin}

Mean interannual rainfall for the whole basin (Figure 17(a)) is of $2200 \mathrm{~mm} / \mathrm{year}$ for a standard deviation of $138 \mathrm{~mm}$ and a variation coefficient of 0.06 . The maximum value, as recorded in 1975 (during a La Niña year), is $2460 \mathrm{~mm}$, whereas the minimum value, recorded in 1992, is $1815 \mathrm{~mm}$ (during an El Niño event).

Trend tests evidence a rainfall decrease during the 1975-2003 period (significant at the 95\% level). The Pearson's, Spearman's and Kendall's coefficient values are $-0.47,-0.50,-0.33$, respectively. This is consistent with the negative trend reported by Marengo (2004) in Brazil. The annual rainfall decrease percentage is $-0.30 \% / y e a r$ ( $-30 \%$ rainfall in 100 years). This is lower than the average calculated in the Peruvian and Ecuadorian Amazon: -0.83\%/year for the 1970-1997 period (Espinoza et al., 2006). All break tests applied to the mean annual rainfall agree with a change in 1982 (Table I), related to the time evolution of the JJA and SON rainfall PC1s (Figure 10) that shows lower rainfall values since 1983 in the north of the basin. The first period, before 1982, outlines an average of $2296 \mathrm{~mm} / \mathrm{year}$ and the second one, after 1982, of $2160 \mathrm{~mm} /$ year. Another change is reported by the Buishand and Pettitt tests in 1989 (with slightly lower values after the break), in partial agreement with the rainfall increase in the northwest observed in PC1 in DJF and PC2 in MAM at the beginning of the 1990s (Figure 13). The first period, before 1989, totals $2250 \mathrm{~mm} /$ year average and the second, after 1989, $2139 \mathrm{~mm}$.

At a quarterly time scale, it clearly appears that rainfall decreases in DJF, JJA, and SON during the 1975-2003 period, with trends being significant at the 95,90 , and 99\% level, respectively (Figure 17(b)). In other words annual rainfall decrease is due to the strong negative trend observed in JJA and SON (Figure 10) in the extreme northwest of the basin that remains rainy during these seasons (Figure 5(a), (b), and (h)). At the end of the century, a positive trend developed from 1992 to 2003 in MAM (at the 95\% significance level) which is consistent with the MAM PC2 (Figure 13), whereas a weak negative trend was found in SON and no trend in DJF and JJA (Figure 17(b)). From a hydrological standpoint, a major finding is the increasing rainfall amplitude which has been observed between SON and MAM since 1992 (Callède et al. 2004; Espinoza et al., 2008).

\section{Conclusions}

For the first time, a database with in situ pluviometric information gathers together 1446 original rain gauges from five countries that form the better part of the AB. Monthly rainfall data have been collected for the 1964-2003 period within the HYBAM programmes, in 


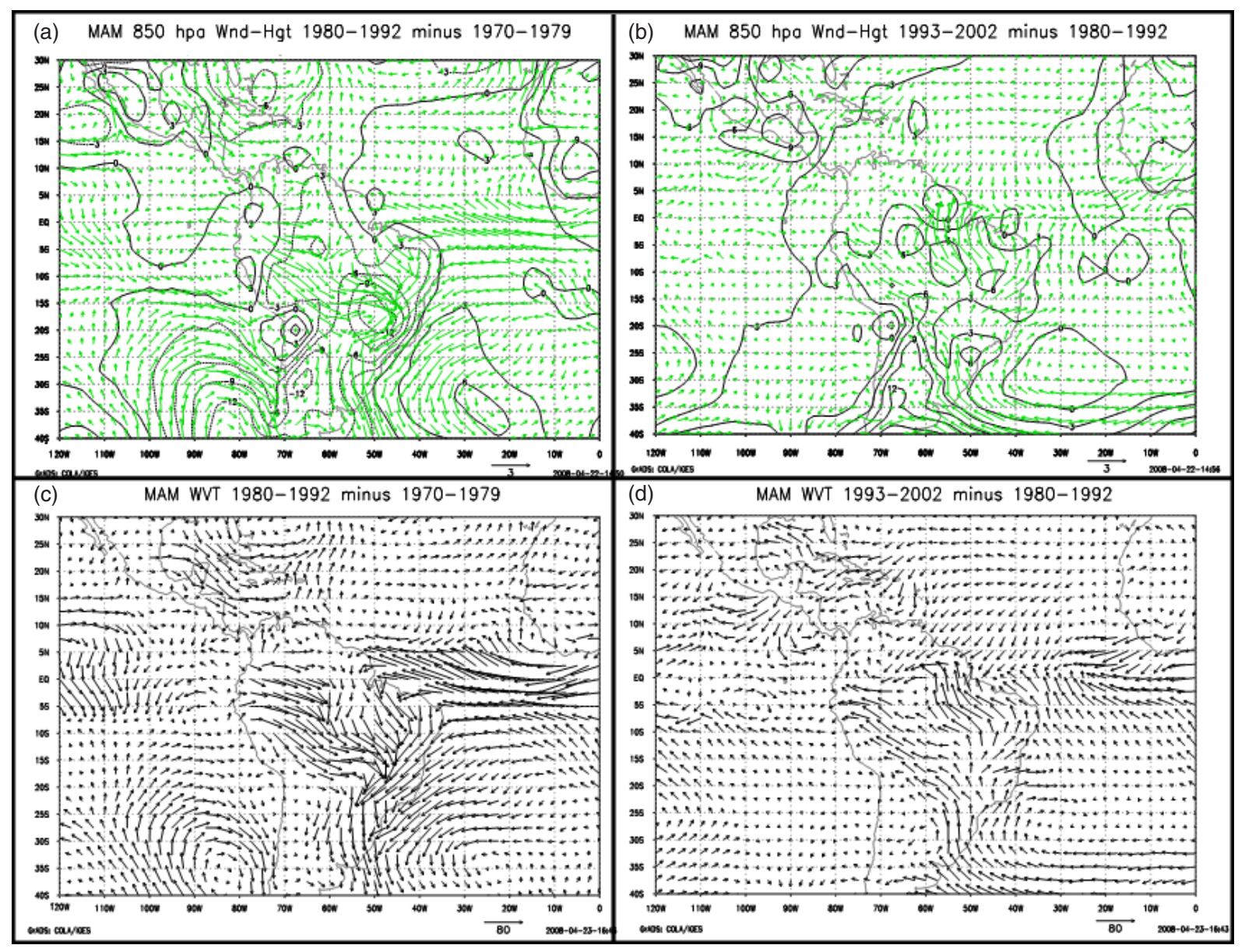

Figure 14. MAM differences between (a) 1980-1992 and 1970-1979 $850 \mathrm{hPa}$ geopotential height (m) and wind (m/s), (b) 1980-1992 and 1970-1979 vertically integrated water vapour flux $(\mathrm{kg} / \mathrm{m} / \mathrm{s})$ between the ground and $500 \mathrm{hPa}$, (c) 1993-2002 and $1980-1992850 \mathrm{hPa}$ geopotential height $(\mathrm{m})$ and wind (m/s), (d) 1993-2002 and 1980-1992 vertically integrated water vapour flux $(\mathrm{kg} / \mathrm{m} / \mathrm{s})$ between the ground and $500 \mathrm{hPa}$. The figures use ECMWF data. This figure is available in colour online at www.interscience.wiley.com/ijoc

collaboration with the different institutions in charge of the meteorological and hydrological monitoring in the Amazonian countries. Rainfall data have been controlled using the RVM. The resulting database (756 stations for the 1964-2003 period) shows that the main data contribution is from the highlands of the Andean countries (Peru, Bolivia, Ecuador, and Colombia). Additionally, the stations are unevenly distributed, with a smaller number of posts in the plain of the Andean countries because of the remoteness of these regions.

In the Andean regions of the $\mathrm{AB}$, very high and low rainfall values (between 6000 and $250 \mathrm{~mm} /$ year) are recorded in nearby stations, as observed in the Himalaya chain by Dobremez (2001). The strong spatial variability is due to rainfall decrease with altitude and to the leeward or windward position of the stations. The highest rainfall in the $\mathrm{AB}$ is observed in low windward regions (over $6000 \mathrm{~mm} / \mathrm{year}$ ) and conversely, low rainfall is measured in leeward and elevated stations (under $530 \mathrm{~mm} /$ year). In the lowlands, the northwest and northeast equatorial regions are the rainiest zones, with values over $3000 \mathrm{~mm} /$ year. Less rainfall is measured in the tropical regions. These results complement what is shown in many studies about rainfall distribution in the
Brazilian Amazon and in particular a focus is given on east-west and north-south rainfall gradients in Peru.

Rainfall regimes evidence the strong opposition between the northern and southern Tropics, because of the alternating warming of each hemisphere and to American monsoons. Next to the Amazon delta, a MAM maximum and a SON minimum are associated with seasonal migration of the ITCZ. In the northwest equatorial region there is a better rainfall distribution within the year with quarterly percentages of rain close to $25 \%$. In the equatorial Andes, the distribution of rainfall regimes is highly complex and associated with the stations exposure: bimodal regimes in intra-Andean basins are found close to unimodal regimes in windward stations. This particular subject is more widely developed in Laraque et al. (2007). Various intermediate regimes are described between equatorial and tropical regions; a focus on Peru is also proposed as very little information is available to this day.

The RVM has supported not only the analysis of data quality, but also the creation of homogeneous regions, exhibiting the same interannual rainfall variability, and computation of 25 indexes (vectors) that summarize the pluviometric variability of 25 regions. PCA has been 

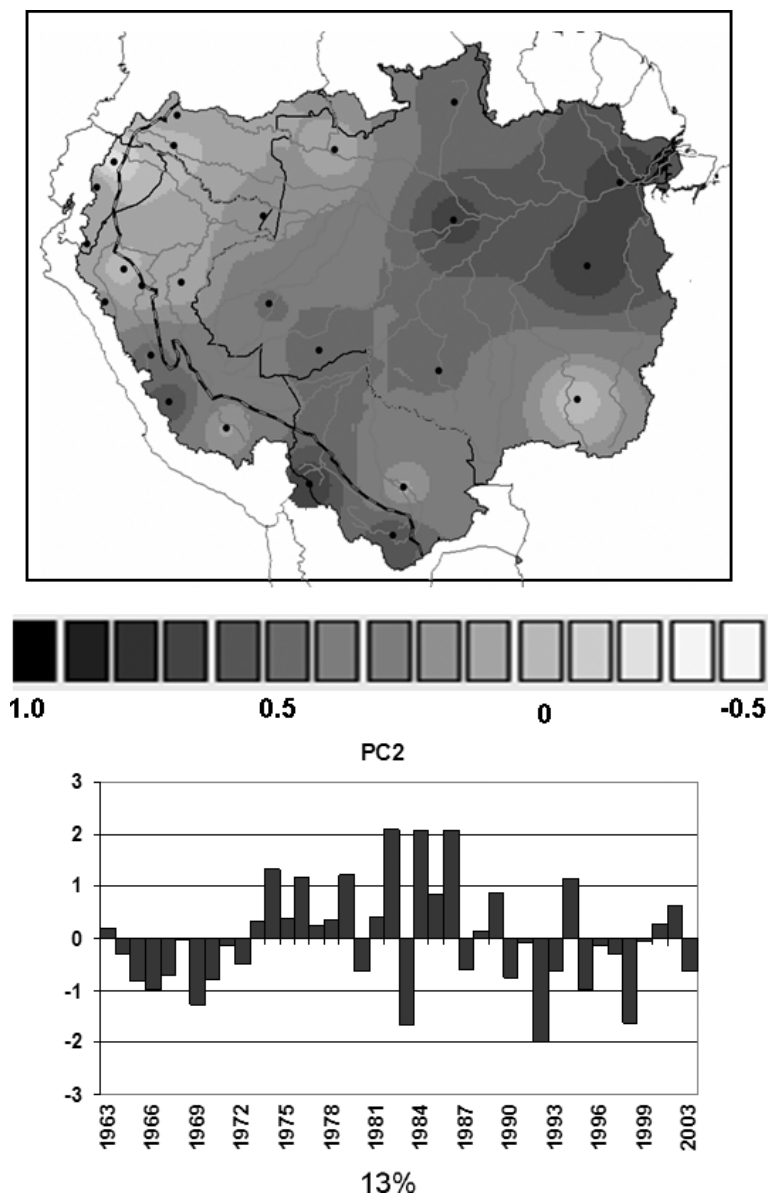

Figure 15. Spatial and temporal patterns associated with the second principal component resulting from a PCA analysis on DJF rainfall in 25 vectors (part 2).

performed on quarterly indexes to identify the main spatial and temporal rainfall patterns. Three main modes of spatio-temporal variability have been defined and the related spatial patterns are widely dependent on the Andean country indexes. A long-term variability characterizes rainfall evolution from June to November. It shows a rainfall decrease since the end of the 1970s-beginning of the 1980s, in the whole basin and especially in the northwest. This change is due to the long-term increase of the near surface geopotential height over the western part of the Amazon. It is also associated with the long- and short-term variability in the Pacific
Ocean (PDO and ENSO). During the rainiest seasons, DJF and MAM, the long-term variability is interrupted at the beginning of the 1990s, featuring a clear NW-SE opposition, with more rainfall in the NW during the 1970s and 1990s and less rainfall during the 1980s; the opposite occurring in the SE. This variability is driven by reduced water vapour transport by the northwest wind along the Andes and the LLJ during the 1990s, which promotes rainfall in the northwest. The opposite conditions causing enhanced rainfall in the south are observed during the 1980s. Finally, an interannual variability in DJF and MAM is related to the Pacific and Atlantic interannual variability. Rainfall is less (more) abundant in the northeastern $\mathrm{AB}$ during El Niño (La Niña) events and when the SST gradient is positive (negative) in the tropical Atlantic. Rainfall is also less abundant over the southern tropical Andes during El Niño, whereas, on the contrary, it tends to be more abundant in the western and southern $\mathrm{AB}$.

The mean rainfall at the outlet of the basin exhibits an average of $2200 \mathrm{~mm} /$ year for the 1975-2003 period. This value is consistent with different results yielding values between 2000 and $2200 \mathrm{~mm}$ for the $\mathrm{AB}$ (Marengo and Nobre, 2001; Marengo, 2004; Callède et al., 2008). The trend during this period is significantly negative and break tests indicate changes in 1982 and 1989 with less rainfall afterwards. The seasonal mean rainfall over the basin shows different evolutions for the 1975-2003 period. Rainfall diminishes dramatically during the drier seasons (JJA and SON) and not so much in DJF and MAM. Opposite trends appear after 1992; rainfall increases in MAM, whereas it decreases in SON. The resulting increase in rainfall amplitude is consistent with the pluriannual variability shown by MAM PC2, i.e. with high rainfall values in the NW and low rainfall values in the south after 1992, and with the break detected in 1989 in the mean rainfall of the basin.

Rainfall decrease is related to changes in the ocean and atmosphere as seen before. However, it may also be associated with deforestation. Unlike what could have been expected, a strong 1975-2003 rainfall decrease is observed during the dry season in the north of the basin, very rainy and undeforested, whereas it is weak in the south which is the most deforested region. To conclude, the assumed deforestation impact on rainfall does not seem to have taken place as expected in the

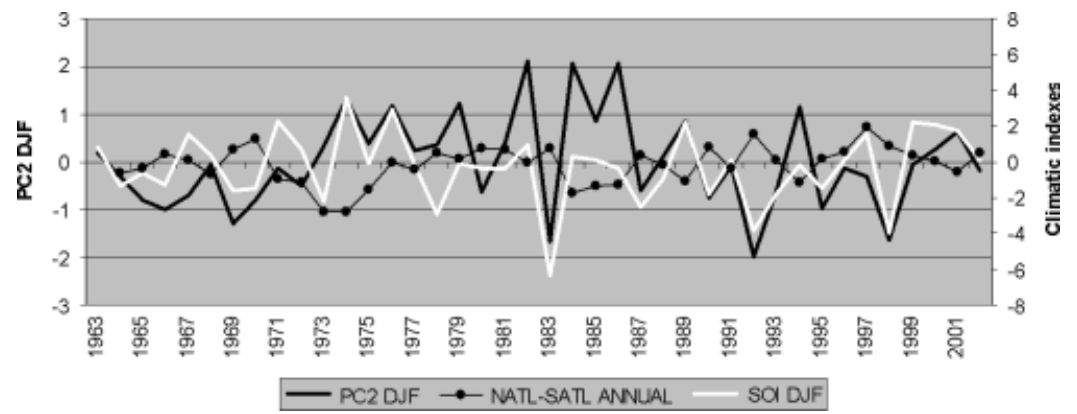

Figure 16. 1963-2003 time evolution of the second PC of a PCA analysis on DJF rainfall, DJF SOI index, and annual NATL-SATL index. 

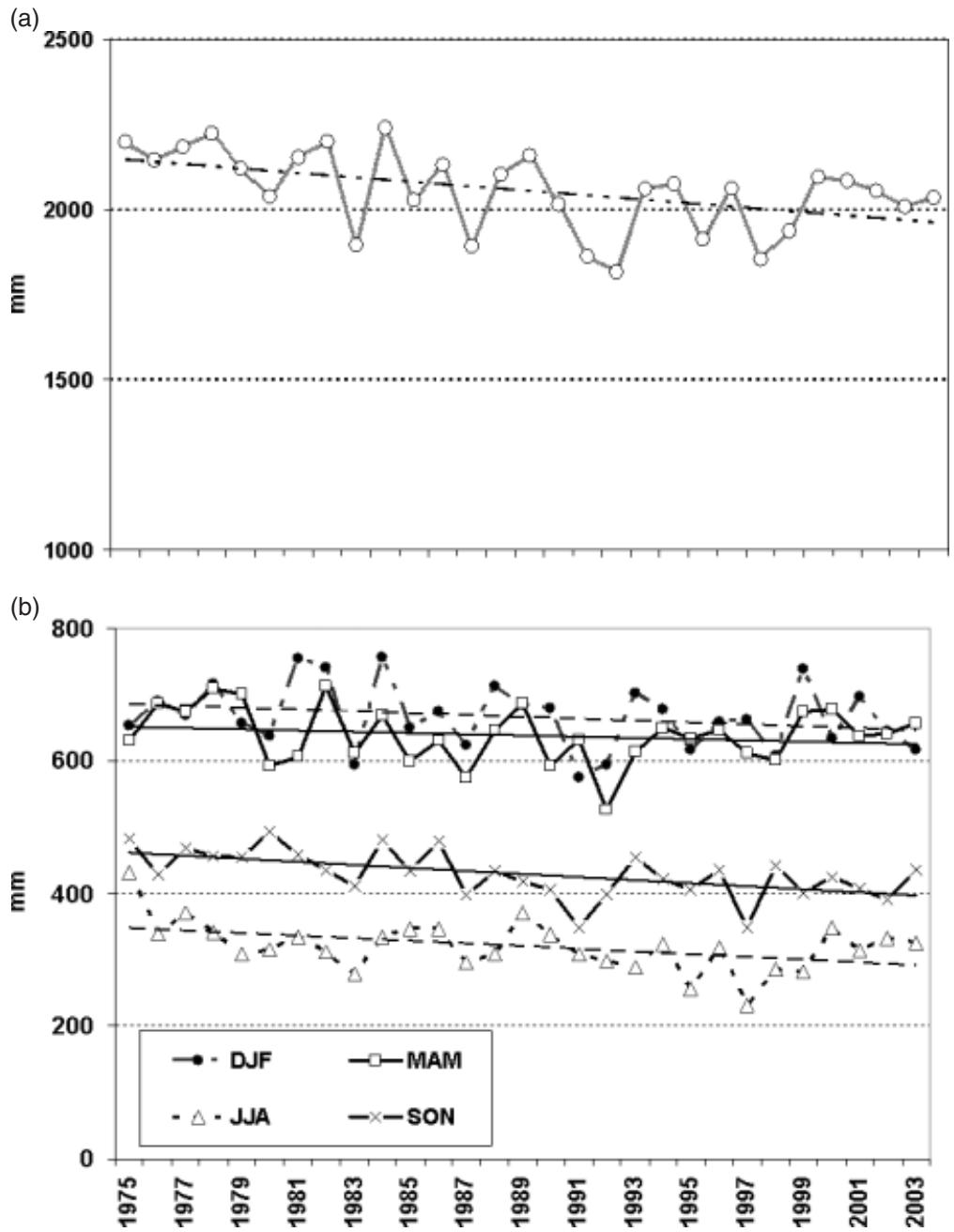

Figure 17. (a) 1975-2003 evolution of the average annual rainfall (mm) in the Amazon basin at the delta and trend line (significant at the 99\% level). (b) 1975-2003 evolution of the average quarterly rainfall (mm) in the Amazon basin at the delta and trend lines DJF, JJA, and SON have significant trends at the 95,90 , and $99 \%$ levels, respectively. In MAM there is no significant trend.

Table I. Results of the break-detecting tests applied on the mean annual rainfall in the AB. ' $\mathrm{X}$ ' indicates a break in the series. Mean, Standard Deviation and Variation Coefficient are given for the 1975-1982 and 1983-2003 periods.

\begin{tabular}{|c|c|c|c|c|c|c|c|}
\hline TEST & 1975 & 1980 & 1985 & 1990 & 1995 & 2000 & 2003 \\
\hline BUISHAND & & $\mathbf{X}$ & & $\mathbf{X}$ & & & \\
\hline PETTITT & & $\mathbf{X}$ & $\mathbf{X}$ & $\mathbf{X}$ & & & \\
\hline LEE ET HEGNINIAN & & $\mathbf{X}$ & & & & & \\
\hline HUBERT & & $\mathbf{X}$ & & & & & \\
\hline Mean rainfall (mm) & & 2158 & & & & & \\
\hline Standard Deviation (mm) & & 59 & & & & & \\
\hline Variation Coefficient & & $\mathbf{0 . 0 3}$ & & & & & \\
\hline
\end{tabular}

most deforested areas. Nevertheless, this issue will have to be further addressed in the future.

Our results are in line with those of Zhou and Lau (2001) who reported interannual, decennial, and interdecadal rainfall variability in South America during the 1979-1995 period. Nonetheless, the introduction of data from the Andean countries, where variability reaches a peak, has a major impact on the spatial structure of rainfall variability. In particular, our study complements the north-south rainfall variability reported by Marengo (1992, 2004).

The description of two modes of long-term rainfall variability leads to a better understanding of runoff evolution in the main stream of the Amazon River (Callède et al., 2004, 2008, and Espinoza et al., 2008), particularly with respect to the intensification of runoff extremes, without taking into account the changes in land use. These results make it possible to identify the location 
with the main spatial temporal rainfall variability in the $\mathrm{AB}$ and as a consequence, highlight those regions where future researches aiming to define the causes of rainfall variability will be conducted. It will be done in order to address such issues as that of knowing whether rainfall variability is related to climate variability, or to climatic change, or to changes in land use such as deforestation. A better insight into regional rainfall variability is also conducive to a greater understanding of the regional runoff variability in the sub-basins of the Amazon, and especially the frequent major floods and very weak lowflows that have recently been observed (Marengo et al., 2008; Zeng et al., 2008).

\section{Acknowledgements}

The authors would like to express their special thanks to the Institute of Research for the Development (IRD) and the French National Center for Scientific Research (CNRS) through the National Program 'Fluid Envelopes and Environment' (LEFE) for funding this research. ECMWF ERA-40 data used in this study have been provided by ECMWF from the ECMWF data server. The authors are grateful to IDEAM (Instituto de Hidrología, Meteorología y Estudios Ambientales - Colombia), SENAMHI (Servicio Nacional de Meteorología e Hidrología - Bolivia and Peru), INAMHI (Instituto Nacional de Meteorología e Hidrología - Ecuador), and ANA (Agência Nacional de Águas - Brazil) for sharing their knowledge of local climate with the authors and for providing the rainfall data. The authors are grateful to the reviewers whose comments and suggestions considerably helped to improve the manuscript.

\section{References}

Aceituno P. 1988. On the functioning of the southern oscillation in the South American sector: surface, climate. Monthly Water Review 116: $505-524$

Aceituno P. 1998. Climate elements of the South American Altiplano. Revista Geofisica - IPGH 44: 37-55.

Agosta E, Compagnucci R, Vargas W. 1999. Cambios en el régimen de la precipitación estival en la región centro-oeste Argentina. Meteorológica 24: 63-84.

Avissar R, Liu Y. 1996. Three-dimensional numerical study of shallow convective clouds and precipitation induced by land surface forcings. Journal of Geophysical Research 101: 7499-7518.

Bendix J, Gämmerler S, Reudenbach C, Bendix A. 2003. A case study on rainfall dynamics during El Niño/La Niña 1997/99 in Ecuador and surrounding areas as inferred from GOES-8 and TRMM - PR observation. Erdkunde 57: 81-93.

Broggy JA. 1965. Climatología general. Boletín de la sociedad geográfica de Lima 84: 30-35.

Brunet-Moret Y. 1979. Homogénéisation des précipitations. Cahiers ORSTOM, Série Hydrologie 16: 3-4.

Buishand TA. 1982. Tests for detecting a shift in the mean of hydrological time series. Journal of Hydrology 58: 51-69.

Buytaert W, Celleri R, Willems P, De Bièvre B, Wyseure G. 2006. Spatial and temporal rainfall variability in mountain areas: A case study from the south Ecuadorian Andes. Journal of Hydrology 329: $413-421$.

Callède J, Guyot JL, Ronchail J, L'Hôte Y, Niel H, de Oliveira E. 2004. Evolution du débit de l'Amazone à Obidos de 1902 à 1999. Hydrological Sciences Journal 49: 85-97.

Callède J, Ronchail J, Guyot JL. 2008. Déboisement amazonien: son influence sur le débit de l'Amazone à Óbidos (Brésil). Revue des Sciences de l'Eau/Journal of Water Science 21: 59-72.
Chen F, Avissar R. 1994. Impact of land-surface moisture variability on local shallow convective cumulus and precipitation in large-scale models. Journal of Applied Meteorology 33: 1382-1401.

Chen TC, Yoon JH, St. Croix KJ, Takle ES. 2001. Suppressing impacts of the Amazon deforestation by the global circulation change. Bulletin of the American Meteorological Society 82: 2210-2216.

Chu PS, Yu ZP, Hastenrath S. 1994. Detecting climate change concurrent with deforestation in the Amazon basin: Which way has it gone? Bulletin of the American Meteorological Society 75: 579-583.

Curtis S, Hastenrath S. 1999. Trend of upper-air circulation and water vapor in the equatorial South America and adjacent oceans. International Journal of Climatology 19: 863-876.

D’Almeida C, Vörösmarty CJ, Hurtt GC, Marengo JA, Dingman SL, Keim BD. 2007. The effects of deforestation on the hydrological cycle in Amazonia: a review on scale and resolution. International Journal of Climatology 27: 633-647.

Dillon W, Goldstein M. 1984. Multivariate analysis. Methods and applications. John Wiley and Sons; New York 157-186.

Dirmeyer P, Shukla J. 1994. Albedo as a modulator of climate response to tropical deforestation. Journal of Geophysical Research 99: 20863-20877.

Dobremez JF. 2001. La Montagne du biologiste. Revue de Géographie Alpine 2: 93-100.

Durieux L, Toledo Machado LA, Laurent H. 2003. The impact of deforestation on cloud cover over the Amazon arc of deforestation. Remote Sensing of Environment 86: 132-140.

Eltahir EAB, Bras RL. 1994. Precipitation recycling in the Amazon Basin. Quarterly Journal of the Royal Meteorological Society 120: $861-880$.

Espinoza JC, Fraizy P, Guyot JL, Ordoñez JJ, Pombosa R, Ronchail J. 2006. La variabilité des débits du Rio Amazonas au Pérou. Climate Variability and Change-Hydrological impacts 308: 424-429, IAHS Publ.

Espinoza JC, Guyot JL, Ronchail J, Cochonneau G, Filizola N, Fraizy P, Noriega L, de Oliveira E, Ordoñez JJ, Vauchel P. 2008. Contrasting regional discharge evolutions in the Amazon basin (1974-2004). Journal of Hydrology (Submitted).

Figueroa SN, Nobre CA. 1990. Precipitation distribution over central and western tropical South America. Climanalise 6: 36-40.

Fisch G, Marengo JA, Nobre CA. 1998. Uma revisão geral sobre o clima da Amazõnia. Acta Amazônica 28: 101-126.

Francou B, Pizarro L. 1985. El Niño y las sequías en los altos Andes centrales (Perú y Bolivia). Bulletin de l'Institut Français d'Etudes Andines 14: 1-18.

Francou B, Vuille M, Wagnon P, Mendoza J, Sicart JE. 2003. Tropical climate change recorded by a glacier in the central Andes during the last decades of the 20th century: Chacaltaya, Bolivia. Journal of Geophysical Research 108(D5): 4059. DOI:10.129/2002JD002473.

Fu R, Dickinson RE, Chen MX, Wang H. 2001. How the tropical sea surface temperatures influence the seasonal distribution precipitation in equatorial Amazonia? Journal of Climate 14: 4003-4026.

Fu R, Zhu B, Dickinson RE. 1999. How the atmosphere and land surface influence seasonal changes of convection in the tropical Amazon? Journal of Climate 12: 1306-1321.

Garreaud R. 2000. Cold air incursions over Subtropical South America: Mean structure and dynamics. Monthly Weather Review 128 2544-2559.

Garreaud R, Aceituno P. 2001. Interannual rainfall variability over the South American Altiplano. Journal of Climate 14: 2779-2789.

Gautier E, Brunstein D, Vauchel P, Roulet M, Fuertes O, Guyot JL, Darrozes J, Bourrel L. 2006. Temporal relations between meander deformation, water discharge and sediment fluxes in the floodplain of the Rio Beni (Bolivian Amazonia). Earth Surface Processes and Landforms 32: 230-248.

Genta J, Perez-Iribarren G, Mechoso G. 1998. A recent increasing trend in streamflow of rivers in southern South America. Journal of Climate 11: 2858-2862.

Grimm AM. 2003. The El Niño impact on the summer monsoon in Brazil: regional processes versus remote influences. Journal of Climate 16: 263-280.

Grimm AM. 2004. How do La Niña events disturb the summer monsoon system in Brazil? Climate Dynamics 22: 123-138.

Guyot JL. 1993. Hydrogéochimie des fleuves de l'Amazonie bolivienne, Editions de l'ORSTOM. Paris, 261.

Henderson-Sellers A, Dickinson RE, Durbidge TB, Kennedy PJ, McGuffie K, Pitman AJ. 1993. Tropical deforestation: modeling local- to regional-scale climate change. Journal of Geophysical Research 98: 7289-7315. 
Hiez G. 1977. L'homogénéité des données pluviométriques. Cahier ORSTOM, série Hydrologie 14: 129-172.

Hiez G, Cochonneau G, Sèchet P, Medeiros Fernandes U. 1991. Aplicação do método do Vetor Regional : analise da pluviometria anual da bacia amazônica. IX Simposio Brasileiro de Recursos Hidricos. ABRH 1: 367-377.

Horel JD, Hahmann AN, Geisler JE. 1989. An investigation of the annual cycle of convective activity over the tropical Americas. Journal of Climate 2: 1388-1403.

Houghton RA, Skole DL, Nobre CA, Hackler JL, Lawrence KT, Chomentowski WH. 2000. Annual fluxes of carbon from deforestation and regrowth in the Brasilian Amazon. Nature 403: 301-304.

Hubert P, Carbonnel JP, Chaouche A. 1989. Segmentation des séries hydrométéorologiques. Application à des séries de précipitations et de débits de l'Afrique de l'Ouest. Journal of Hydrology 110 349-367.

Institut de Recherche pour le Développement (IRD). 2002 KHRONOSTAT: Software for statistical analysis of chronological series, www.mpl.ird.fr/hydrologie/gbt/projets/iccare/khronost.htm.

Johnson AM. 1976. The climate of Peru, Bolivia and Ecuador. Climates of Central and South America, World Survey of Climatology, Vol. 12. Elsevier Scientific Publishing Company; New York 147-218, Chap 4.

Kendall MG. 1975. Rank Correlation Methods. Griffin.

Kousky VE, Kayano MT, Cavalcanti IFA. 1984. A review of the southern oscillation: oceanic, atmospheric circulation changes and related anomalies. Tellus 36A: 490-504.

Laraque A, Ronchail J, Cochonneau G, Pombosa R, Guyot JL. 2007. Heterogeneous distribution of rainfall and discharge regimes in the Ecuadorian Amazon basin. Journal of Hydrometeorology 8 1364-1381.

Lau KM, Wu HT. 2006. Detecting trends in tropical rainfal characteristics, 1979-2003. International Journal of Climatology 27 979-988.

Lee AFS, Heghinian SM. 1977. A shift of the mean level in a sequence of independent normal random variables-A bayesian approach Technometrics 19: 503-506.

Le Tourneau FM. 2004. Jusqu'au bout de la forêt? Causes et mécanismes de la déforestation en Amazonie brésilienne. M@ppemonde 75, http://mappemonde.mgm.fr/num3/articles/ art04307.html.

Liebmann B, Marengo JA. 2001. Interannual variability of the rainy season and rainfall in the Brazilian Amazonia. Journal of Climate 14: $4308-4318$.

Mantua NJ, Hare SR, Zhang Y, Wallace JM, Francis RC. 1997. A Pacific interdecadal climate oscillation with impacts on salmon production. Bulletin of the American Meteorological Society 78 1069-1079.

Marengo JA. 1992. Interannual variability of surface climate in the Amazon basin. International Journal of Climatology 12: 853-863.

Marengo JA. 2004. Interdecadal variability and trends of rainfall across the Amazon basin. Theoretical and Applied Climatology 78: 79-96.

Marengo JA, Hastenrath S. 1993. Case studies of extreme climatic events in the Amazon basin. Journal of Climate 6: 617-627.

Marengo JA, Nobre CA. 2001. General characteristics and variability of climate in the Amazon basin and its links to the global climate system. In The Biochemistry of the Amazon basin, Clain ME, Victoria RL, Richey JE (eds). Oxford University Press; UK, 17-41.

Marengo JA, Nobre CA, Tomasella J, Oyama MD, de Oliveira GS, de Oliveira R, Camargo H, Alves LM. 2008. The drought in Amazonia in 2005. Journal of Climate 21: 495-516.

Marengo JA, Soares WR, Saulo C, Nicolini M. 2004. Climatology of the Low Level Jet East of the Andes as derived from the NCEPNCAR reanalysis. Characteristics and temporal variability. Journal of Climate 17: 2261-2280.

Marquez J, Salati E, Marden Dos Santos J. 1980. A divergência do campo fluxo de vapor d'água e as chuvas na região amazônica. Acta Amazônica 10: 133-140.

Matsuyama H, Marengo JA, Obregón GO, Nobre CA. 2002. Spatial and temporal variabilities of rainfall in tropical South America as derived from climate prediction center merged analysis of precipitation. International Journal of Climatology 22: 175-195.

Mialocq L, Acuña M, Seyler F, Yerren J, Guyot JL. 2005. Extraction of the topographic limits of the Andean and Amazonian rivers basin from SRTM. Paper presented at the workshop on: Isotope tracers and remote sensing techniques for assessing water cycle variability, VII th. IAHS Scientific Assembly, Foz do Iguaçu, 3-9 April 2005.
Molinier M, Guyot JL, Oliveira E, Guimarães V. 1996. Les régimes hydrologiques de l'Amazone et de ses affluents. L'hydrologie Tropicale: Géoscience et outil pour le Développement 238: 209-222, Paris, Mai 1995. IAHS Publ..

Molion LCB. 1987. Climatologia dinâmica da região Amazônica: mecanismos de precipitação. Revista Brasileira de Metodologia 2: $107-117$.

Molion LCB. 1993. Amazonian rainfall and its variability. Hydrological and Water Management in the Humid Tropics. Cambridge University press: Cambridge; $99-111$.

Moron V, Bigot S, Roucou P. 1995. Rainfall variability in subequatorial America and Africa and relationships with the main sea-surface temperature modes (1951-1990). International Journal of Climatology 15: 1297-1322.

Nicholson C. 1948. Ensayo de la clasificación de los climas del Perú. Boletín de la Sociedad Geográfica de Lima 65: 3-8.

Nobre CA. 1983. Amazonia and Climate. Proc. Of the WMO technical conf. on climate for Latin America and the Caribbean. Colombia WMO, 409-416.

Nobre CA, Sellers P, Shukla J. 1991. Amazonian deforestation and regional climate change. Journal of Climate 4: 957-988.

Nobre P, Shukla J. 1996. Variation of sea surface temperature, wind stress and rainfall over the tropical Atlantic and South America. Journal of Climate 9: 2469-2479.

Oliveira AS, Nobre CA. 1986. Meridional penetration of frontal systems in South America and its relation to organized convection in the Amazon, Publication INPE-3407-PRE/676.

Pettitt AN. 1979. A non-parametric approach to the change-point problem. Applied Statistics 28: 126-135.

Polcher J, Laval K. 1994. A statistical study of the regional impact of deforestation on climate in the LMD GCM. Climate Dynamics 10: 205-219.

Poveda G. 2004. La hidroclimatología de Colombia: Una síntesis desde la escala interdecadal hasta la escala diurna. Revista de la Academia da Ciencias 28: 201-222.

Poveda G, Mesa OJ. 1993. Metodologías de predicción de la hidrología colombiana considerando el evento de El Niño Oscilación del Sur (ENOS), Atmósfera. Sociedad Colombiana de Meteorología, 17.

Poveda G, Waylen P, Pulwarty R. 2006. Annual and Inter-annual Variability of Present Climate in Northern South America and Southern Mesoamerica. Palaeogeography, Palaeoclimatolgy, Palaeoecology 234(1): 3-27.

Pulwarty RS, Barry RG, Hurst CM, Sellinger K, Mogollon LF. 1998. Precipitation in the Venezuelan Andes in the context of regional climate. Meteorology and Atmospheric Physics 67: 217-237.

Ratisbona LR. 1976. The climate of Brazil. Climates of Central and South America, World Survey of Climatology, Vol. 12. Elsevier Scientific Publishing Company; New York, 219-293, chap. 5.

Rao VB, Cavalcanti IFA, Hada K. 1996. Annual variation of rainfall over Brazil and water vapor characteristics over South America. Journal of Geophysical Research 101: 26539-26551.

Robertson AW, Mechoso CR. 1998. Interanual and decadal cycles in river flow of southeastern of South America. Journal of Climate 11: $2570-2581$.

Roche MA, Aliaga A, Campos J, Pena J, Cortes J, Rocha N. 1990. Hétérogénéité des précipitations sur la cordillère des Andes boliviennes, Hydrology in Mountainous Regions. I-Hydrological Measurements; the Water Cycle, IAHS 193, 381-388.

Rome S, Ronchail J. 1998. La pluviométrie au Pérou pendant les phases ENSO et LNSO. Bulletin de l'Institut Française d'Etudes Andines 27: 675-685.

Ronchail J. 1989. Advections Polaires en Bolivie: mise en évidence et caractérisation des effets climatiques. Hydrologie Continentale 4: $49-56$.

Ronchail J. 1996. Variabilité pluridécénale des précipitations en Bolivie. Essai de mise en relation avec les températures de surface océaniques de l'Atlantique extra-tropical. Publication de l' Association Internationale de Climatologie 9: 504-511.

Ronchail J. 1998. Variabilité pluviométrique en Bolivie lors de phases extrêmes de l'Oscillation Australe du Pacifique (1950-1993). Bulletin de l'Institut Francais d'Etudes Andines 27: 687-698.

Ronchail J, Bourrel L, Cochonneau G, Vauchel P, Phillips L, Castro A, Guyot JL, de Oliveira E. 2005. Climate and inundation in the Mamoré basin (South-Western Amazon - Bolivia). Journal of Hydrology 302: 223-238.

Ronchail J, Cochonneau G, Molinier M, Guyot JL, Goretti de Miranda Chaves A, Guimarães V, de Oliveira E. 2002. Rainfall variability in the Amazon Basin and SSTs in the tropical Pacific and Atlantic oceans. International Journal of Climatology 22: 1663-1686. 
Ronchail J, Gallaire R. 2006. ENSO and rainfall along the Zongo valley (Bolivia) from the Altiplano to the Amazon basin. International Journal of Climatology 26: 1223-1236.

Rossel F, Goulven PL, Cadier E. 1999. Areal distribution of the influence of ENSO on the annual rainfall in Ecuador. Revue des Sciences de l'Eau/Journal of Water Science 12: 183-200.

Salati E, Marquez J, Molion LC. 1978. Origem e distribuição das chuvas na Amazônia. Interciencia 3: 200-205.

Salati E, Vose PB. 1984. Amazon basin: a system in equilibrium. Science 225: 129-138.

Saulo AC, Nicolini M, Chou SC. 2000. Model characterization of the South American low-level flow during the 1997-1998 springsummer season. Climate Dynamics 16: 867-881.

Seluchi M, Marengo JA. 2000. Tropical-midlatitude exchange of air masses during summer and winter in South America: climates aspects and examples of intense events. International Journal of Climatology 20: 1167-1190.

Shukla J, Nobre CA, Sellers P. 1990. Amazon deforestation and climate change. Science 247: 1322-1325.

Siegel S, Castellan NJ. 1988. Non-Parametric Statistics for the Behavioural Sciences. McGraw-Hill; USA.

Silva Dias MAF, Rutledge S, Kabat P, Silva Dias PL, Nobre CA, Fisch G, Dolman AJ, Zipser E, Garstang M, Manzi AO, Fuentes JD, da Rocha HR, Marengo JA, Plana-Fattori A, S'a LDA, Alval'a RCS, Andreae MO, Artaxo P, Gielow R, Gatti L. 2002. Cloud and rain processes in a biosphere-atmosphere interaction context in the Amazon Region. Journal of Geophysical Research 107, DOI 10.1029/2001JD000335.

Tapley TD, Waylen PR. 1990. Spatial variability of annual precipitation and ENSO events in western Peru. Hydrological Sciences Journal 35 : 429-445.

Trenberth KE, Hurrell JW. 1994. Decadal atmosphere - ocean variations in the Pacific. Climate Dynamics 9: 303-319.

Uppala SM, Kållberg PW, Simmons AJ, Andrae U, da Costa Bechtold V, Fiorino M, Gibson JK, Haseler J, Hernandez A, Kelly GA, Li X, Onogi K, Saarinen S, Sokka N, Allan RP, Andersson E, Arpe K, Balmaseda MA, Beljaars ACM, van de Berg L, Bidlot J, Bormann N, Caires S, Chevallier F, Dethof A, Dragosavac M, Fisher M, Fuentes M, Hagemann S, Hólm E,
Hoskins BJ, Isaksen L, Janssen PAEM, Jenne R, McNally AP, Mahfouf JF, Morcrette JJ, Rayner NA, Saunders RW, Simon P, Sterl A, Trenberth KE, Untch A, Vasiljevic D, Viterbo P, Woollen J. 2005. The ERA-40 re-analysis. Quarterly Journal of the Royal Meteorological Society 131: 2961-3012.

Uvo CB, Repelli CA, Zebiak SE, Kushnir Y. 1998. The relationship between Tropical Pacific and Atlantic SST and northeast Brazil monthly precipitation. Journal of Climate 11: 551-562.

Vauchel P. 2005. Hydraccess: Software for Management and processing of Hydro - meteorological data software, Version 2.1.4 Free download www.mpl.ird.fr/hybam/utils/hydracces.htm.

Vuille M, Bradley R, Keiming F. 2000. Interannual climate variability in the clentral Andes and its relation to tropical Pacific and Atlantic forcing. Journal of Geophysical Research 105: $12447-12460$

Wagnon P, Ribstein P, Francou B, Sicart JE. 2001. Anomalous heat and mass budget of Glacier Zongo, Bolivia, during the 1997/98 E1 Niño year. J. Glaciol. 47: 21-28.

Wang J, Bras RL, Eltahir EAB. 2000. The impact of observed deforestation on the mesoscale distribution of rainfall and clouds in Amazonia. Journal of Hydrometeorology 1: 267-286.

Weberbauer A. 1945. El Mundo Vegetal de los Andes Peruanos, Studio Fitogeográfico. Ministerio de Agricultura: Lima. Perú.

Wolter K, Timlin MS, 1993. Monitoring ENSO in COADS with a seasonally adjusted principal component index. Proc. of the 17th Climate Diagnostics Workshop, Norman, OK, NOAA/N MC/CAC NSSL, Oklahoma Clim. Survey, CIMMS and the School of Meteor., Univ. of Oklahoma, 52-57.

Zbigniew WK. 2004. Change detection in hydrological records - a review of the methodology. Hydrological Sciences Journal 49: 7-119.

Zeng N, Yoon J, Marengo J, Subramaniam A, Nobre C, Mariotti A, Neelin JD. 2008. Causes and impact of the 2005 Amazon drought. Environmental Research Letters 3: 9.

Zhou J, Lau KM. 1998. Does a monsoon climate exist over South America? Journal of Climate 11: 1020-1040.

Zhou J, Lau KM. 2001. Principal modes of interannual and decadal variability of summer rainfall over South America. International Journal of Climatology 21: 1623-1644. 